\title{
Distribution of the Tetrodotoxin-Resistant Sodium Channel PN3 in Rat Sensory Neurons in Normal and Neuropathic Conditions
}

\author{
Sanja D. Novakovic, Elda Tzoumaka, Joseph G. McGivern, Miki Haraguchi, Lakshmi Sangameswaran, \\ Kathleen R. Gogas, Richard M. Eglen, and John C. Hunter
}

Center for Biological Research, Neurobiology Unit, Roche Bioscience, Palo Alto, California 94304-1397

The novel sodium channel PN3/ $\alpha$-SNS, which was cloned from a rat dorsal root ganglion (DRG) cDNA library, is expressed predominantly in small sensory neurons and may contribute to the tetrodotoxin-resistant $\left(\mathrm{TTX}_{\mathrm{R}}\right)$ sodium current that is believed to be associated with central sensitization in chronic neuropathic pain states. To assess further the role of PN3, we have used electrophysiological, in situ hybridization and immunohistochemical methods to monitor changes in $\mathrm{TTX}_{\mathrm{R}}$ sodium current and the distribution of PN3 in normal and peripheral nerve-injured rats. (1) Whole-cell patch-clamp recordings showed that there were no significant changes in the TTX $\mathrm{R}_{\mathrm{R}}$ and TTX-sensitive sodium current densities of small DRG neurons after chronic constriction injury $(\mathrm{CCl})$ of the sciatic nerve. (2) Additionally, in situ hybridization showed that there was no change in the expression of PN3 mRNA in the DRG up to $14 \mathrm{~d}$ after $\mathrm{CCl}$. PN3 mRNA was not detected in sections of brain and spinal cord taken from either normal or nerve-injured rats. (3) In contrast, immunohistochemical studies showed that major changes in the subcellular distribution of PN3 protein were caused by either $\mathrm{CCl}$ or complete transection of the sciatic nerve. The intensity of PN3 immunolabeling decreased in small DRG neurons and increased in sciatic nerve axons at the site of injury. The alteration in immunolabeling was attributed to translocation of presynthesized, intracellularly located PN3 protein from neuronal somata to peripheral axons, with subsequent accumulation at the site of injury. The specific subcellular redistribution of PN3 after peripheral nerve injury may be an important factor in establishing peripheral nerve hyperexcitability and resultant neuropathic pain.

Key words: PN3; sodium channel; tetrodotoxin-resistant; distribution; sensory neuron; neuropathic pain; chronic constriction injury; neuroma; nociception
Hyperexcitability originating at ectopic sites is a major feature of injured neurons (Devor, 1995). Because sodium channels play an important role in the control of membrane excitability, it is not surprising that the drugs of choice in the clinical treatment of neuropathic pain include local anesthetics and anticonvulsants (Tanelian and Victory, 1995), agents that can inhibit neuronal sodium channels. In animal models of sciatic nerve injury, electrophysiological recordings have shown that hyperexcitability and spontaneous discharges develop both at the site of injury and at the dorsal root ganglion (DRG) cell bodies (Xie et al., 1995), possibly the result of a lowered threshold potential (Study and Kral, 1996). Computer simulations have shown that an increase in sodium channel density may cause hyperexcitability by lowering the threshold potential (Matzner and Devor, 1992). In support of this hypothesis, sodium channel accumulation at sites of injury has been demonstrated using immunohistochemical (Devor et al., 1993) and ligand-binding (Lombet et al., 1985) techniques. In addition, suppression of ectopic electrogenesis in injured peripheral nerve has been demonstrated with sodium channel inhibitors such as lidocaine (Chabal et al., 1989; Matzner and Devor, 1994), tetrodotoxin (TTX) (Matzner and Devor, 1994; Omana-Zapata et al., 1997), carbamazepine (Burchiel, 1988), phenytoin (Yaari and Devor, 1985), and QX-314 (Bley et al., 1995).

At least two types of sodium currents can be recorded in small neurons of rat DRG (Caffrey et al., 1992). These currents include

Received Nov. 10, 1997; revised Dec. 29, 1997; accepted Jan. 6, 1998.

Correspondence should be addressed to Dr. Sanja Novakovic, Department of Analgesia, Center for Biological Research, Roche Bioscience, 3401 Hillview Avenue, Palo Alto, CA 94304-1397.

Copyright (C) 1998 Society for Neuroscience $\quad 0270-6474 / 98 / 182174-14 \$ 05.00 / 0$ fast, TTX-sensitive $\left(\mathrm{TTX}_{\mathrm{S}}\right)$ currents and slow, TTX-resistant $\left(\mathrm{TTX}_{\mathrm{R}}\right)$ currents (Kostyuk et al., 1981; Elliott and Elliott, 1993; Ogata and Tatebayashi, 1993). Multiple sodium channel $\alpha$-subunits are known to be expressed in DRG, e.g., the $\mathrm{TTX}_{\mathrm{S}}$ channels, brain types I, II, and III, glial, atypical (Waxman et al., 1994; Sangameswaran et al., 1996), and PN1/hNE (Sangameswaran et al., 1997; Toledo-Aral et al., 1997), and the TTX $_{\mathrm{R}}$ channel PN3/ $\alpha$-SNS (Akopian et al., 1996; Sangameswaran et al., 1996). Because of their rapid repriming kinetics, $\mathrm{TTX}_{\mathrm{R}}$ sodium channels probably contribute to sustained firing of nociceptors in neuropathic conditions (Jeftinija, 1994a). In addition, $\mathrm{TTX}_{\mathrm{R}}$ sodium channels are predominantly localized in capsaicin-sensitive DRG neurons (Arbuckle and Docherty, 1995), and these neurons can be excited by agents such as bradykinin (Jeftinija, 1994b). It has also been shown that the $\mathrm{TTX}_{\mathrm{R}}$ sodium channel in DRG neurons is subject to modulation by $\mathrm{PGE}_{2}$, via cAMP-dependent phosphorylation (S. England et al., 1996; Gold et al., 1996).

Several recent studies have investigated the effects of sciatic nerve transection on the expression of sodium channel subtypes in sensory neurons. In situ hybridization experiments showed an increase in the expression of brain type III (Waxman et al., 1994) and a reduction in expression of $\alpha$-SNS in small and large neurons (Dib-Hajj et al., 1996). In apparent agreement with these findings, axotomy attenuated the $\mathrm{TTX}_{\mathrm{R}}$ sodium current but did not affect the $\mathrm{TTX}_{\mathrm{S}}$ sodium current in small neurons (Cummins and Waxman, 1997).

To define the role of $\mathrm{TTX}_{\mathrm{R}}$ sodium channels in a model of neuropathic pain, we have used electrophysiology to investigate changes in the $\mathrm{TTX}_{\mathrm{R}}$ sodium currents in small DRG neurons from rats with chronic constriction injury (CCI) and in situ hy- 
bridization and immunocytochemical methods to study the cellular and subcellular localization of PN3 mRNA and protein in the DRG of CCI and axotomized rats.

\section{MATERIALS AND METHODS}

Animals. Surgical and experimental protocols used in a study were approved by the Institutional Animal Care and Use Committee of Roche Bioscience and conformed to the guidelines for ethical research of the International Association for the Study of Pain (Zimmerman, 1983). Male Sprague Dawley rats (Harlan, Indianapolis, IN) were housed in groups of three under a $12 \mathrm{hr}$ light/dark cycle for 1 week before surgery.

CCI model. A mononeuropathy was produced in rats as described (Bennett and Xie, 1988). Briefly, animals were anesthetized with pentobarbital sodium ( $65 \mathrm{mg} / \mathrm{kg}$, i.p.), and the right sciatic nerve was exposed at midthigh level by blunt dissection through the biceps femoris. In the experimental group of rats, four loose ligatures (chromic gut 4.0; Ethicon) were tied around the nerve, proximal to the trifurcation, but in the sham group the nerve was left untouched. The incisions were closed in layers using 4-0 vicryl-braided suture, and the animals were allowed to recover for a period of $5 \mathrm{~d}$.

The rats were tested for cold allodynia and heat hyperalgesia. For the cold allodynia test, each rat was placed on a metal platform that was submerged in a bath of ice-cold water. The latency for withdrawal of the right hindpaw was measured. Rats were deemed to be allodynic if the average withdrawal latency from three trials was $<13 \mathrm{sec}$ ( $20 \mathrm{~min}$ interval between trials; maximum immersion time, $20 \mathrm{sec}$ ). For the thermal hyperalgesia assay, the latency of hindpaw withdrawal from a radiant heat source was measured. The average latencies of left (nonligated) and right (ligated) hindpaws were obtained from four trials, and a difference score was calculated. Rats were deemed to be hyperalgesic if the difference score was $>1.5 \mathrm{sec}$. We have found previously that CCI animals exhibit maximal cold allodynia from day 4 to day 10 post-surgery (PS) and maximal heat hyperalgesia from day 10 to day 14 PS. Consequently, day 6 and day 13 PS were chosen to routinely perform cold allodynia and radiant heat assays, respectively. Animals that tested positive in both assays were euthanized, and tissues were removed for further analysis.

Neuroma model. The right sciatic nerve was exposed at midthigh level and transected proximal to the trifurcation. A short length $(1 \mathrm{~mm})$ of the distal end was excised to prevent regrowth, resulting in neuroma formation (Devor and Bernstein, 1982). The incision was closed in layers, and the rats were allowed to recover. Sham animals underwent the same surgery except that their nerves were not transected.

Electrophysiology. The L4 and L5 DRG were removed from the operated side of 22 rats (10 allodynic and 12 sham) and were pooled according to group. The ganglia were enzymatically dissociated $(1 \mathrm{mg} / \mathrm{ml}$ collagenase and $1 \mathrm{mg} / \mathrm{ml}$ trypsin) before being plated onto $35 \mathrm{~mm}$ petri dishes. The dishes were then mounted on an inverted microscope for recording purposes.

Sodium currents were recorded from single neurons within $24 \mathrm{hr}$ of isolation using the whole-cell patch-clamp technique (Hamill et al., 1981) at room temperature $\left(20^{\circ} \mathrm{C}\right)$. The following solutions were used to isolate sodium currents: extracellular (in $\mathrm{mM}$ ) $\mathrm{NaCl} 20, \mathrm{KCl} 3$, HEPES 10 , D-glucose $5, \mathrm{CaCl}_{2} 1, \mathrm{MgCl}_{2} 1, \mathrm{CdCl}_{2} 0.5$, choline chloride 140 , sucrose 60 , adjusted to $\mathrm{pH} 7.3$ with $\mathrm{NaOH}$; intracellular (in mM) CsF $120, \mathrm{NaCl}$ 10, HEPES 10, EGTA 11, TEACl $10, \mathrm{CaCl}_{2} 1, \mathrm{MgCl}_{2} 1$, adjusted to $\mathrm{pH}$ 7.3 with $\mathrm{CsOH}$. Recording pipettes were constructed from borosilicate glass (type 7052 from Garner Glass Company, Claremont, CA, or World Precision Instruments, Sarasota, FL) to have resistances of 1-2 M $\Omega$ after fire-polishing and filling. Neurons were clamped using an Axopatch $200 \mathrm{~A}$ patch-clamp amplifier (Axon Instruments, Foster City, CA). The voltageclamp protocols were generated on a computer controlling a Digidata 1200 Interface (Axon Instruments), using PClamp software (version 6.0.3; Axon Instruments). Whole-cell currents were leak-subtracted $(\mathrm{P} /-4)$, low-pass filtered (5 kHz, four-pole Bessel), digitized (20 kHz), and stored on magnetic medium for off-line analysis with Axograph software (version 2.0; Axon Instruments).

Each cell was held at a membrane potential $\left(V_{\text {hold }}\right)$ of $-100 \mathrm{mV}$, and sodium currents were generated by depolarizing steps ( $40 \mathrm{msec}$ in duration) to a range of test potentials $(-90$ to $+50 \mathrm{mV})$ in $10 \mathrm{mV}$ increments. First, total sodium current was recorded at each test potential. Subsequently, $1 \mu \mathrm{M}$ TTX was added to the perfusate for $5 \mathrm{~min}$, and then the $\mathrm{TTX}_{\mathrm{R}}$ current was recorded. The $\mathrm{TTX}_{\mathrm{S}}$ current was determined by subtraction of $\mathrm{TTX}_{\mathrm{R}}$ current waveform from the total current waveform at each test potential. The peak amplitudes of the currents were mea- sured and converted to sodium conductances by means of the following equation:

$$
G_{\mathrm{Na}}=\frac{I_{\mathrm{Na}}}{V_{\text {test }}-V_{\text {rev }}}
$$

where $G_{\mathrm{Na}}$ is the sodium conductance, $I_{\mathrm{Na}}$ is the sodium current, $V_{\text {test }}$ is the test potential, and $V_{\text {rev }}$ is the reversal potential for the sodium current. The sodium conductances were plotted as a function of test potential to generate the conductance-voltage relationship. The data points of this graph were described by the following Boltzmann function:

$$
G_{\mathrm{Na}}=\frac{G_{\mathrm{Na}(\max )}}{1+\exp \left(\frac{V_{\text {test }}-V_{\text {half }}}{k}\right)}
$$

where $G_{\mathrm{Na}(\max )}$ is the maximum sodium conductance, $V_{\text {half }}$ is the test potential that activates $50 \%$ of the sodium channels, $k$ is the slope factor of the curve, and the other terms are as above. Cell capacitance was used as a measure of cell size and was estimated by the electronic cancellation circuitry on the amplifier. To correct the sodium conductance for cell size, the total, $\mathrm{TTX}_{\mathrm{R}}$, and $\mathrm{TTX}_{\mathrm{S}}$ sodium conductances for each cell were normalized with respect to the capacitance of that cell.

Animal perfusion and tissue preparation. Selected rats were anesthetized with $10 \%$ chloral hydrate $(300 \mathrm{mg} / \mathrm{kg})$ and subsequently perfused through the aorta with sodium PBS $\left(200 \mathrm{ml}, \mathrm{pH} 7.5,4^{\circ} \mathrm{C}\right)$, followed by $10 \%$ formalin $\left(500 \mathrm{ml}, \mathrm{pH} 7.8,4^{\circ} \mathrm{C}\right)$. The brain, DRG (L4 and $\left.\mathrm{L} 5\right)$, and lumbar spinal cord were removed, post-fixed ( $10 \%$ formalin, overnight, $4^{\circ} \mathrm{C}$ ), processed in xylenes and ethanols (tissue processor from Miles Scientific, Elkhart, IN) and embedded in paraffin blocks. Next, 4- to $10-\mu \mathrm{m}$-thick sections were cut, mounted on slides (Probe-On Plus, Fisher Scientific, Pittsburgh, PA), and air-dried, first at room temperature and then in a forced-air dryer $\left(20 \mathrm{~min}, 60^{\circ} \mathrm{C}\right)$. For nonradioactive in situ hybridization, the same procedure was used but in RNase-free conditions. Alternatively, for cryosectioning, rats were perfused, and the tissue was harvested quickly, cryoprotected by incubation in PBS-sucrose, embedded in OCT Tissue Tek, and frozen on dry ice. Next, 10 or $20 \mu \mathrm{m}$ cryosections were cut and mounted on gelatin-coated slides to be used for radioactive in situ hybridization or in immunofluorescent labeling.

Teased nerve fibers. The sciatic nerve was dissected from perfused or nonperfused rats and post-fixed in $4 \%$ formaldehyde for $4 \mathrm{hr}$. The nerve was then cleaned, desheathed, and dissociated with collagenase/dispase (Boehringer Mannheim, Indianapolis, IN) $\left(3.5 \mathrm{mg} / \mathrm{ml}, 60 \mathrm{~min}, 35^{\circ} \mathrm{C}\right)$. Axons were gently teased apart with fine needles, spread over coverslips that had been coated in a few places with Cell-Tak (Collaborative Biochemical Products, Bedford, MA), and air-dried before immunocytochemistry.

In situ hybridization. Oligonucleotide probes were synthesized from a unique $3^{\prime}$-untranslated region of PN3 (Biosource International, Camarillo, CA). Sense probe was made complementary to the antisense for use in control experiments. The procedure for radioactive in situ hybridization has been described previously (Sangameswaran et al., 1996). Briefly, cryosections were thawed, digested in proteinase $\mathrm{K}(1 \mu \mathrm{g} / \mathrm{ml})$ for $1 \mathrm{hr}$ at $37^{\circ} \mathrm{C}$, dehydrated in ethanols $(50-100 \%)$, and air-dried. Hybridization was performed overnight at $39^{\circ} \mathrm{C}$ in a solution containing ${ }^{35} \mathrm{~S}$ ATP-labeled oligonucleotides (specific activity, $5 \times 10^{7}$ to $1 \times 10^{8}$ $\mathrm{cpm} / \mu \mathrm{g}), 50 \%$ formamide, $4 \times \mathrm{SSC}, 0.5 \mathrm{mg} / \mathrm{ml}$ salmon sperm DNA, and $1 \times$ Denhardt's solution. Sections were washed over a period of $6 \mathrm{hr}$ in $2 \times$ to $0.1 \times$ SSC containing $0.1 \% \beta$-mercaptoethanol, dehydrated in a series of ethanols (50-100\%) containing $0.3 \mathrm{M}$ ammonium acetate, and apposed to sheet film (Amersham $B_{\max }$ ) or dipped in liquid emulsion (Amersham LM-1) and then developed for 2 and 5 weeks, respectively.

For nonradioactive in situ hybridization, paraffin-embedded sections were deparaffinized in xylenes and ethanols, permeabilized with Triton $\mathrm{X}-100(0.3 \%, 15 \mathrm{~min}$, room temperature $)$, pepsin $(0.1 \%)$ in $\mathrm{HCl}(0.2 \mathrm{M}$, $\left.10 \mathrm{~min}, 37^{\circ} \mathrm{C}\right)$, and proteinase $\mathrm{K}\left(10 \mu \mathrm{g} / \mathrm{ml}, 30 \mathrm{~min}, 37^{\circ} \mathrm{C}\right)$. After the permeabilization, sections were post-fixed in $4 \%$ formaldehyde $(5 \mathrm{~min})$, washed in PBS, and acetylated on a shaking platform with acetic anhydride $(0.25 \%$ in triethanolamine buffer, $\mathrm{pH} 8$, room temperature). Sections were prehybridized for $2 \mathrm{hr}$ at $37^{\circ} \mathrm{C}$ in a hybridization solution containing $2 \times$ SSC buffer, $1 \times$ Denhardt's solution, $10 \%$ dextran sulfate, $250 \mu \mathrm{g} / \mathrm{ml}$ yeast t-RNA, $0.05 \mathrm{pmol} / \mathrm{ml}$ of Randomer Oligoprobe (DuPont, Billerica, MA), $0.1 \mathrm{mg} / \mathrm{ml}$ poly(A) (Boehringer Mannheim, Indianapolis, IN), $500 \mu \mathrm{g} / \mathrm{ml}$ of denatured salmon testis DNA, and $50 \%$ deionized formamide. Hybridization was performed in the same solution 

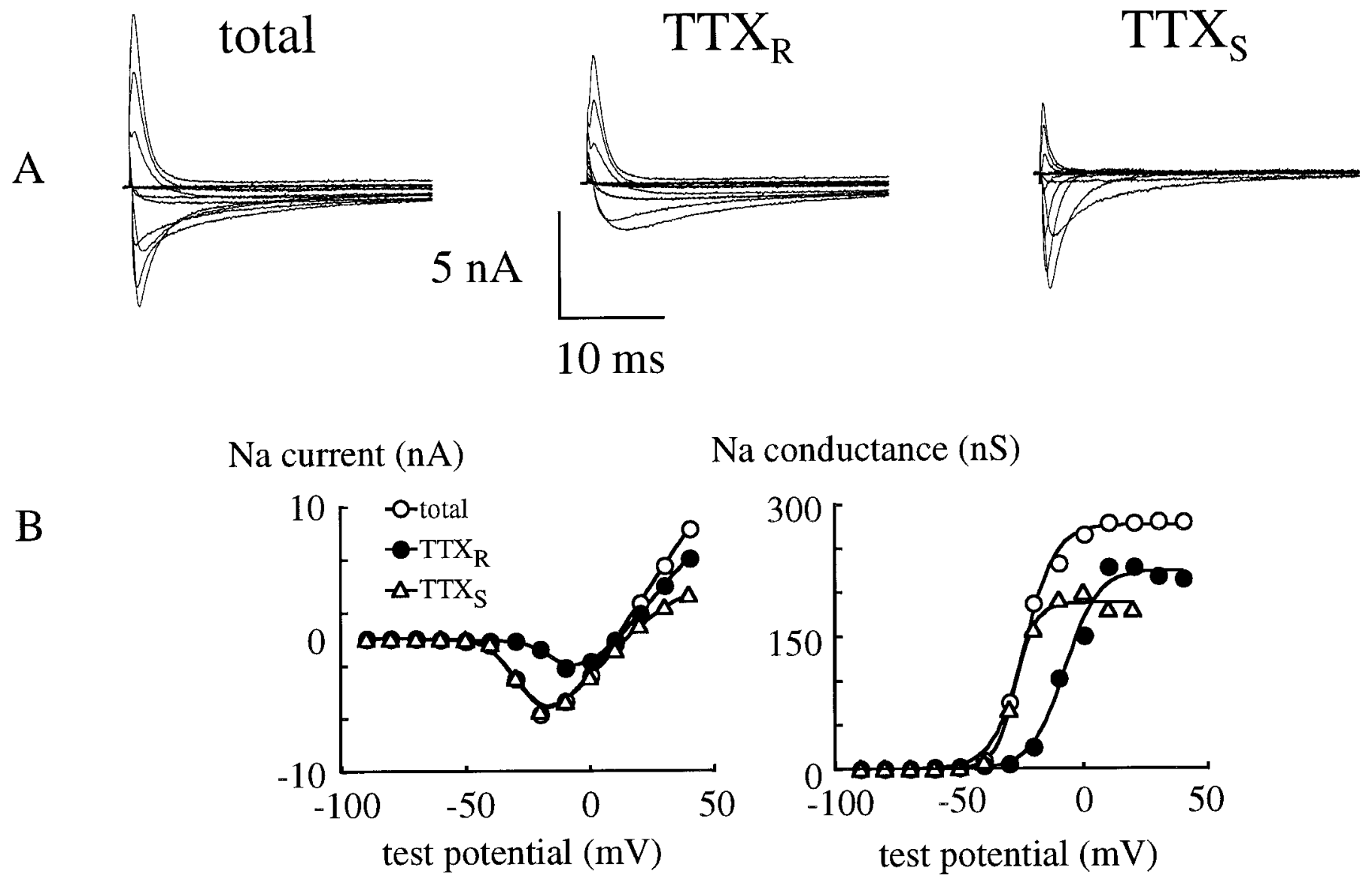

Na conductance (nS)

Figure 1. Isolation of $\mathrm{TTX}_{\mathrm{R}}$ and $\mathrm{TTX}_{\mathrm{S}}$ sodium currents. $A$, Total, $\mathrm{TTX}_{\mathrm{R}}$, and $\mathrm{TTX}_{\mathrm{S}}$ sodium currents were recorded from a single DRG neuron taken from a nerve-injured rat. Sodium currents were evoked by stepping from a holding potential of $-100 \mathrm{mV}$ to a range of test potentials $(-90$ to $+40 \mathrm{mV})$ for $40 \mathrm{msec}$. Currents were recorded before and $5 \mathrm{~min}$ after application of $1 \mu \mathrm{M}$ TTX to the cell. $B, I-V$ and $G-V$ relationships were plotted for total, $\mathrm{TTX}_{\mathrm{R}}$, and $\mathrm{TTX}_{\mathrm{S}}$ sodium currents (same neuron as in $A$ ).

\begin{tabular}{llll}
\hline \multicolumn{4}{l}{ Table 1. Sodium conductance densities in DRG neurons } \\
Conductance & Sham-operated & Nerve-injured & $p$ \\
\hline Total $(\mathrm{nS} / \mathrm{pF})$ & $8.0 \pm 0.8$ & $8.5 \pm 0.8$ & $>0.05$ \\
$\operatorname{TTX}_{\mathrm{S}}(\mathrm{nS} / \mathrm{pF})$ & $4.1 \pm 0.5$ & $5.2 \pm 0.7$ & $>0.05$ \\
$\operatorname{TTX}_{\mathrm{R}}(\mathrm{nS} / \mathrm{pF})$ & $6.3 \pm 0.7$ & $6.6 \pm 0.8$ & $>0.05$
\end{tabular}

Comparison of sodium conductance densities in small DRG neurons taken from nerve-injured and sham-operated rats. A total of 14 neurons from nerve-injured rats and 15 neurons from sham-operated rats were studied. Data are presented as mean \pm SEM.

containing specific antisense or sense oligoprobe, overnight at $37^{\circ} \mathrm{C}$ or $40^{\circ} \mathrm{C}$. After hybridization, samples were washed with $2 \times, 1 \times$, and $0.25 \times$ SSC buffer twice for $15 \mathrm{~min}$ at $37^{\circ} \mathrm{C}$ each, followed by one rinse in buffer A (100 mm Tris- $\mathrm{HCl}, 150 \mathrm{~mm} \mathrm{NaCl}, \mathrm{pH}$ 7.5). Next, samples were incubated in blocking solution (buffer $\mathrm{A}+0.1 \%$ Triton X-100 $+10 \%$ goat serum, $1 \mathrm{hr}$, room temperature) and then in anti-digoxigenin antibodies conjugated with alkaline phosphatase $(2 \mathrm{hr}$, room temperature). Samples were subsequently washed in buffer A and incubated briefly in detection buffer (buffer $\mathrm{A}+50 \mathrm{mM} \mathrm{MgCl} \mathrm{M}_{2}$ ) and then in color solution (200 $\mu \mathrm{M}$ nitro-blue tetrazolium/5-bromo-4-chloro-3-indolyl phosphate (NBT/BCIP), Boehringer Mannheim Detection Kit; $10 \mathrm{ml}$ of detection buffer with $10 \mathrm{~mm}$ levamisol) overnight in the dark. Alternatively, the fluorescence substrate for alkaline phosphatase (Boehringer Mannheim) was used instead of NBT/BCIP. On the following day, sections were washed with water and mounted with either Krystalon (color substrate) or special antifading medium (fluorescence). Antifading medium was made as follows: $8 \mathrm{gm}$ polyvinyl alcohol was added to $40 \mathrm{ml}$ of $0.2 \mathrm{M}$ Tris- $\mathrm{HCl}, \mathrm{pH} 8.5$, and dissolved by heating to $50^{\circ} \mathrm{C}$. After cooling, $20 \mathrm{ml}$ glycerol was added, as well as $2 \% 1,4$ diazoabicyclo(2,2,2)octane (DABCO) to reduce photobleaching. The medium was centrifuged and stored in aliquots at $-20^{\circ} \mathrm{C}$.

Quantification of hybridization. Morphometric analysis was performed after radioactive in situ hybridization as described previously (Sangameswaran et al., 1996). Sections were visualized by a computerlinked camera, and the area of individual neurons was determined by tracing the cell margins on a computer screen. Only clearly identifiable, nucleolated DRG neurons were used for analysis. For simplicity, arbitrary criteria categorized neurons with areas of $1200 \mu \mathrm{m}^{2}$ as "small and medium" and neurons $>1200 \mu \mathrm{m}^{2}$ as "large." For a cell to be considered hybridized, its grain density was required to be subjectively several times higher than background levels. Data were categorized according to hybridization status, and histograms were generated to determine PN3 mRNA distribution as a function of cell size. NIH Image program was used for image capturing and quantification of cell area.

Antisera. Two different antisera were used in the course of the study. Site-directed polyclonal antibodies were raised against peptides found in the PN3 protein sequence: CDPNLPNSNGSRGNC (Peptide I, located in domain IV between S5 and S6, antiserum 20075) or APYLGESWKRKDSPQVAE (Peptide II, located in the intracellular loop between domains II, region 6, and III, region 1, antiserum 20073). Peptides were conjugated with KLH and injected into rabbits (Research Genetics). Antisera were purified on a peptide affinity column before use in immunocytochemistry. Because Peptide I shares a sequence common to that of the cardiac sodium channel, the immunocytochemical protocol had to be modified. A long fixation period was used to destroy the cardiac channel antigenicity (see Fig. 4), thereby allowing the PN3 antigen to be specifically detected.

Immunohistochemistry. After deparaffinization in xylenes and ethanols, microscope slides were mounted in the Microprobe slide holder 

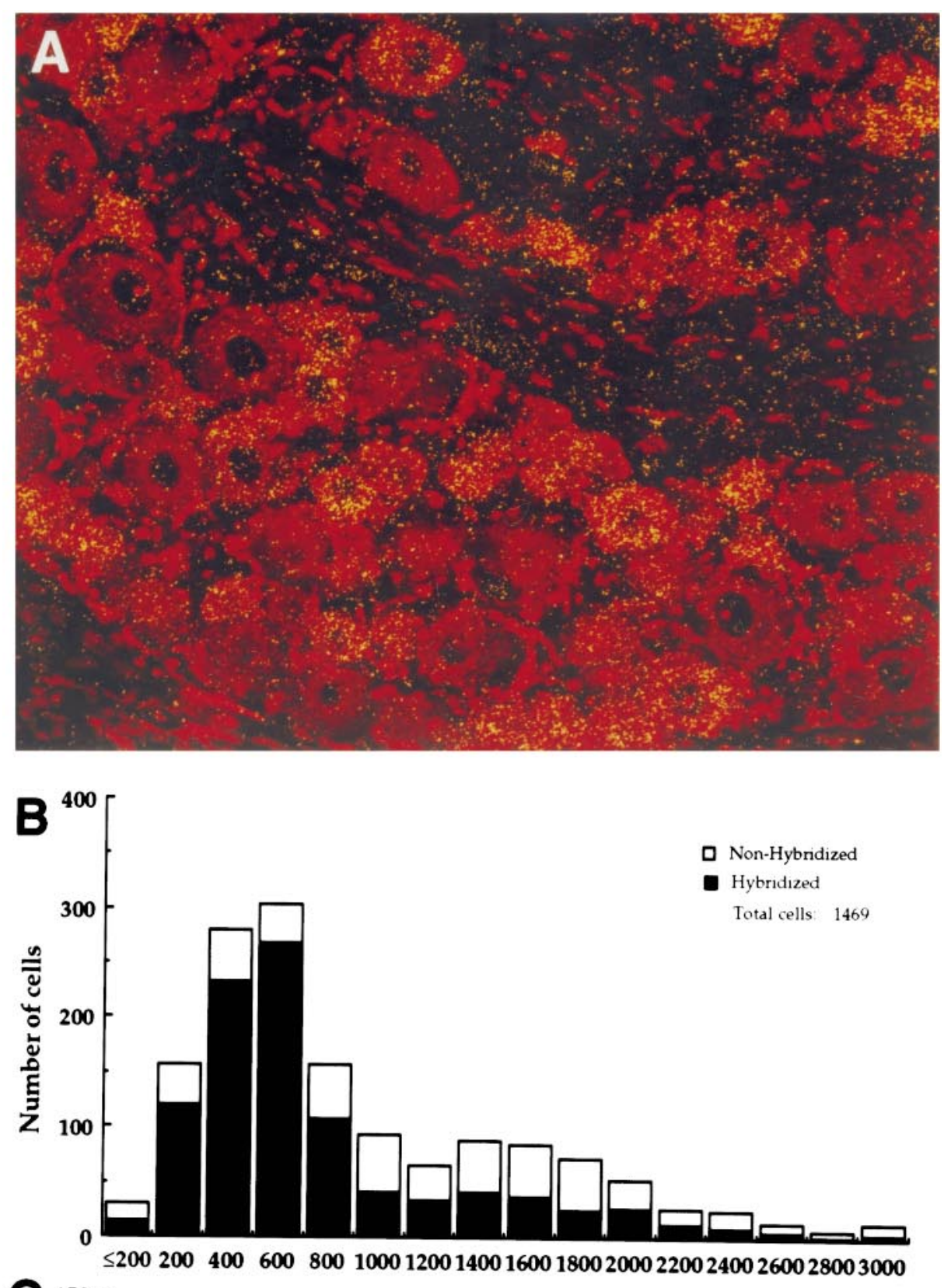

Figure 2. Radioactive in situ hybridization showing distribution of PN3 mRNA in the rat DRG neurons. $A$, Normal DRG tissue, $10-\mu \mathrm{m}$ thick cryosections. Emulsion autoradiography of the section hybridized with antisense probe. PN3 mRNA is localized predominantly in small DRG neurons, and strong cytoplasmic signals could be observed. Some large neurons have low-level labeling. Cell nuclei are not labeled. $B$, Distribution of hybridization by cell size in the normal DRG tissue. $C$, Distribution of hybridization in the CCI tissue. No significant differences were observed.

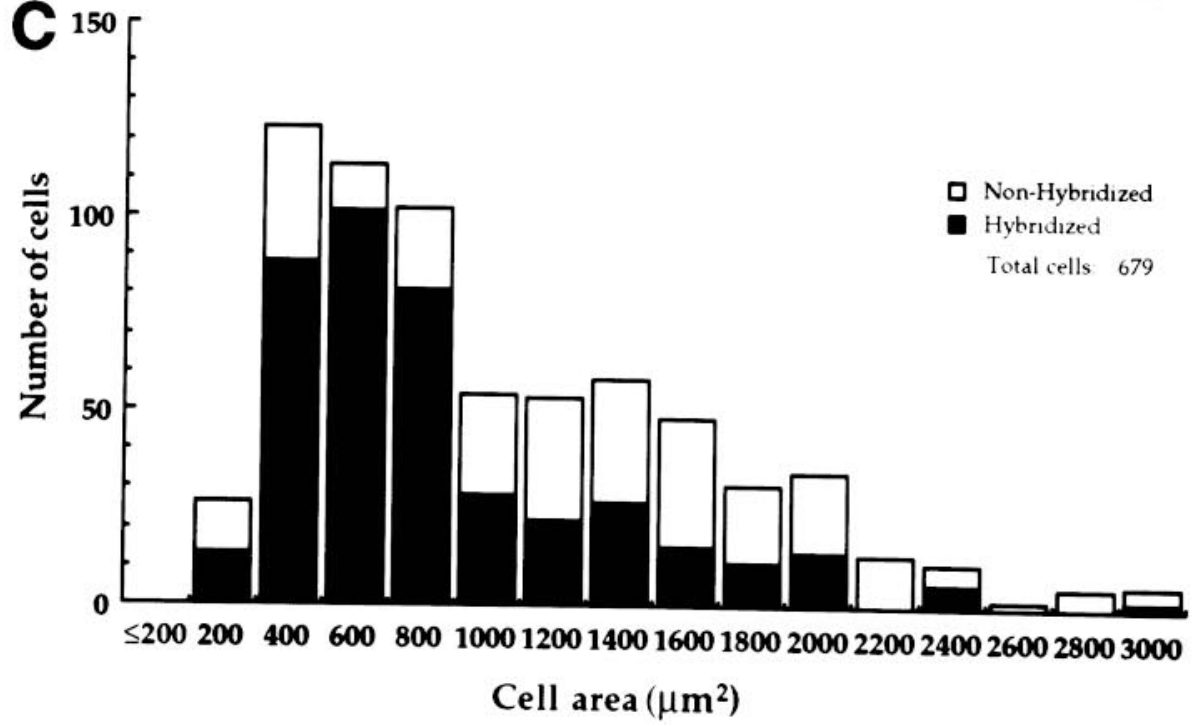


(Fisher Scientific), where the "capillary gap" between adjacent slides allowed for the filling and retaining of liquid during incubation. Sections were preincubated in potassium PBS (KPBS) containing 20\% normal goat serum (NGS) and $0.2 \%$ Triton X-100 (1 hr, room temperature), and then incubated in KPBS containing $5 \%$ NGS, $0.2 \%$ Triton X-100, and PN3 antibodies at 1:50 to 1:200 dilution (overnight, $4^{\circ} \mathrm{C}$ ). The next day, sections were washed in KPBS containing $0.1 \%$ bovine serum albumin (BSA) and $0.1 \%$ Triton X-100 ( $2 \mathrm{hr}$, room temperature), incubated in the secondary antibody solution (biotinylated anti-rabbit IgG 1:200, Vectastain Elite Kit; $1 \mathrm{hr}$, room temperature), washed again, and then incubated with peroxidase avidin-biotin complex (ABC, 1:50, $90 \mathrm{~min}$, room temperature). After a few washes with $0.1 \mathrm{M} \mathrm{KPB}$, the staining pattern was visualized with a DAB substrate reaction (Zymed Laboratories, San Francisco, CA). Tissue sections were then washed, dehydrated in a series of ethanols and xylenes, and mounted with Krystalon. For immunofluorescence, ABC was substituted with extra-avidin-FITC antibodies (1:200, $1 \mathrm{hr})$, and slides were mounted with the antifading medium. Alternatively, 20- $\mu \mathrm{m}$-thick cryosections were used for immunolabeling with primary antibodies diluted up to $1: 1000$. For teased nerve fibers, a hydrophobic slide marker (pap pen) was used to circle the samples on slides, and all solutions were applied directly to slides. Chinese Hamster Lung (CHL) cells were also labeled to control antibody specificity. Before immunocytochemistry, CHL cells were washed with PBS and fixed in $4 \%$ formaldehyde (30 min, room temperature). The same procedure was followed as for the immunofluorescence labeling of tissue sections, and PN3 antibodies were used at 1:3000 dilution. In some experiments propidium iodide (Molecular Probes, Eugene, OR) (1:2000, $1 \mathrm{hr}$, room temperature) was used for nonspecific labeling of cell nuclei. For control experiments, antibodies were preabsorbed with the peptide antigen overnight at $4^{\circ} \mathrm{C}$.

Quantification of immunolabeling. A Nikon Microphot SA microscope with fluorescent attachment and a Bio-Rad MRC 1024 confocal microscope were used for sample observation. IPLab Spectrum (Signal Analytics) program was used for image capturing and quantification of cell area and labeling intensity. To measure cell area, each individual neuron was painted as a segment including the nuclear region, but for the measurements of labeling intensity, the nucleus was excluded. According to the measured area, neurons were classified as small $\left(<700 \mu \mathrm{m}^{2}\right)$, medium (700-1200 $\left.\mu \mathrm{m}^{2}\right)$, and large $\left(1200 \mu \mathrm{m}^{2}\right)$.

Statistical comparisons. The current densities of neurons taken from neuropathic and sham-operated animals were compared using the unpaired Student's $t$ test. The statistical analysis of intensity of labeling in neurons from CCI and sham-operated animals was performed with a two-sample $t$ test.

\section{RESULTS}

\section{Sodium currents do not change after chronic constriction injury}

Sodium currents were recorded from 14 DRG neurons taken from neuropathic $(\mathrm{CCI})$ rats and from 15 neurons taken from sham-operated rats, at $12 \mathrm{~d}$ PS. The average cell capacitances of the two groups of neurons were not significantly different, suggesting that currents were measured from the same type of neuron in each group (neuropathic, $29.0 \pm 1.5 \mathrm{pF}$; sham, $25.4 \pm$ $1.2 \mathrm{pF} ; p>0.05$ ). Figure $1 A$ shows the sodium currents recorded from a single DRG neuron that was taken from a nerve-injured rat. Total sodium current was recorded in the absence of TTX, 5 min after attainment of the whole-cell voltage-clamp configuration. The $\mathrm{TTX}_{\mathrm{R}}$ sodium current was recorded after a 5 min extracellular application of $1 \mu \mathrm{M}$ TTX, and the TTX $_{\mathrm{S}}$ sodium current was obtained by digital subtraction of the $\mathrm{TTX}_{\mathrm{R}}$ waveforms from the total sodium current waveforms. Figure $1 B$ illustrates the current-voltage and the conductance-voltage relationships for total, $\mathrm{TTX}_{\mathrm{R}}$, and $\mathrm{TTX}_{\mathrm{S}}$ sodium currents in this neuron.

To correct the sodium conductances for cell size, the total, $\mathrm{TTX}_{\mathrm{R}}$, and TTX $\mathrm{T}_{\mathrm{S}}$ sodium conductances for each cell were normalized with respect to the capacitance of that cell. The results for the sodium conductance densities for all cells studied are summarized in Table 1. There were no statistically significant

\begin{tabular}{|c|c|c|c|c|}
\hline Group & Cell size & $\begin{array}{l}\text { Number of } \\
\text { neurons }\end{array}$ & $\begin{array}{l}\text { Number of } \\
\text { neurons } \\
\text { hybridized }\end{array}$ & $\begin{array}{l}\% \\
\text { hybridized }\end{array}$ \\
\hline \multirow[t]{2}{*}{ Normal } & Small and medium & 1105 & 850 & 77 \\
\hline & Large & 364 & 160 & 44 \\
\hline \multirow[t]{2}{*}{ Neuropathic } & Small and medium & 455 & 337 & 74 \\
\hline & Large & 224 & 87 & 39 \\
\hline
\end{tabular}

$\overline{\text { A total of } 16 \text { sections from normal rats and } 7 \text { from neuropathic rats containing } 1469}$ and 679 neurons, respectively, were examined for PN3 hybridization. Area of each neuron was measured by digital tracing. Neurons with area $<1200 \mu \mathrm{m}^{2}$ were categorized as small and medium, and neurons with area $>1200 \mu \mathrm{m}^{2}$ as large. For a cell to be considered hybridized, its grain density was required to be subjectively several times higher than background level. Only clear, nucleolated neurons were counted.

differences in the sodium conductance densities among neurons taken from nerve-injured and sham-operated rats.

\section{PN3 mRNA is expressed predominantly in small DRG neurons and does not change after chronic constriction injury}

Previously, functional expression in Xenopus oocytes showed that PN3 is a voltage-gated sodium channel with a depolarized activation potential, slow inactivation kinetics, and resistance to high concentration of TTX (Sangameswaran et al., 1996). Radioactive in situ hybridization of normal DRG sections revealed a distinctive pattern of PN3 mRNA localization (Fig. 2A), as observed previously (Sangameswaran et al., 1996). PN3 mRNA was highly expressed in small DRG neurons and was visualized as high density labeling in the cytoplasmic region. This was in contrast to the absent or low level labeling in large neurons (Fig. 2A). The pattern was the same if a fluorescent or color substrate was used in the nonradioactive method (not shown). Hybridization with a sense probe resulted only in nonspecific hybridization, seen as diffuse background labeling. PN3 mRNA was not detected in spinal cord or brain tissue, confirming findings with Northern blots and RT-PCR analysis (Sangameswaran et al., 1996) and indicating that PN3 is expressed exclusively in the peripheral nervous system.

Quantification of hybridization was performed after radioactive in situ hybridization. Neurons were examined for PN3 hybridization in 16 sections from normal rats and in seven sections from CCI rats, 14 d PS, containing 1469 and 679 cells, respectively. The area of each neuron was measured by digital tracing. Figure $2 B$ illustrates PN3 mRNA distribution by cell size in normal tissue. In DRG taken from CCI rats the distribution by size (Fig. 2C) and the number of neurons expressing PN3 mRNA (74\% of small and medium neurons and $39 \%$ of large neurons) did not differ significantly from normal values (77\% of small and medium and $44 \%$ of large neurons) (Table 2). This result was also confirmed with RT-PCR analysis (not shown).

\section{Immunohistochemistry confirms that PN3 channels are localized predominantly in small DRG neurons}

Immunofluorescent labeling of PN3-transfected and naive (nontransfected) CHL cells was performed as a control of antibody specificity. Approximately $30-40 \%$ of transfected cells labeled specifically and brightly with $\mathrm{PN} 3$ antiserum (Fig. $3 A$, green). Immunolabeling for PN3 was very faint in all nontransfected cells (Fig. $3 B$ ), comparable to that seen with preabsorbed antibodies 

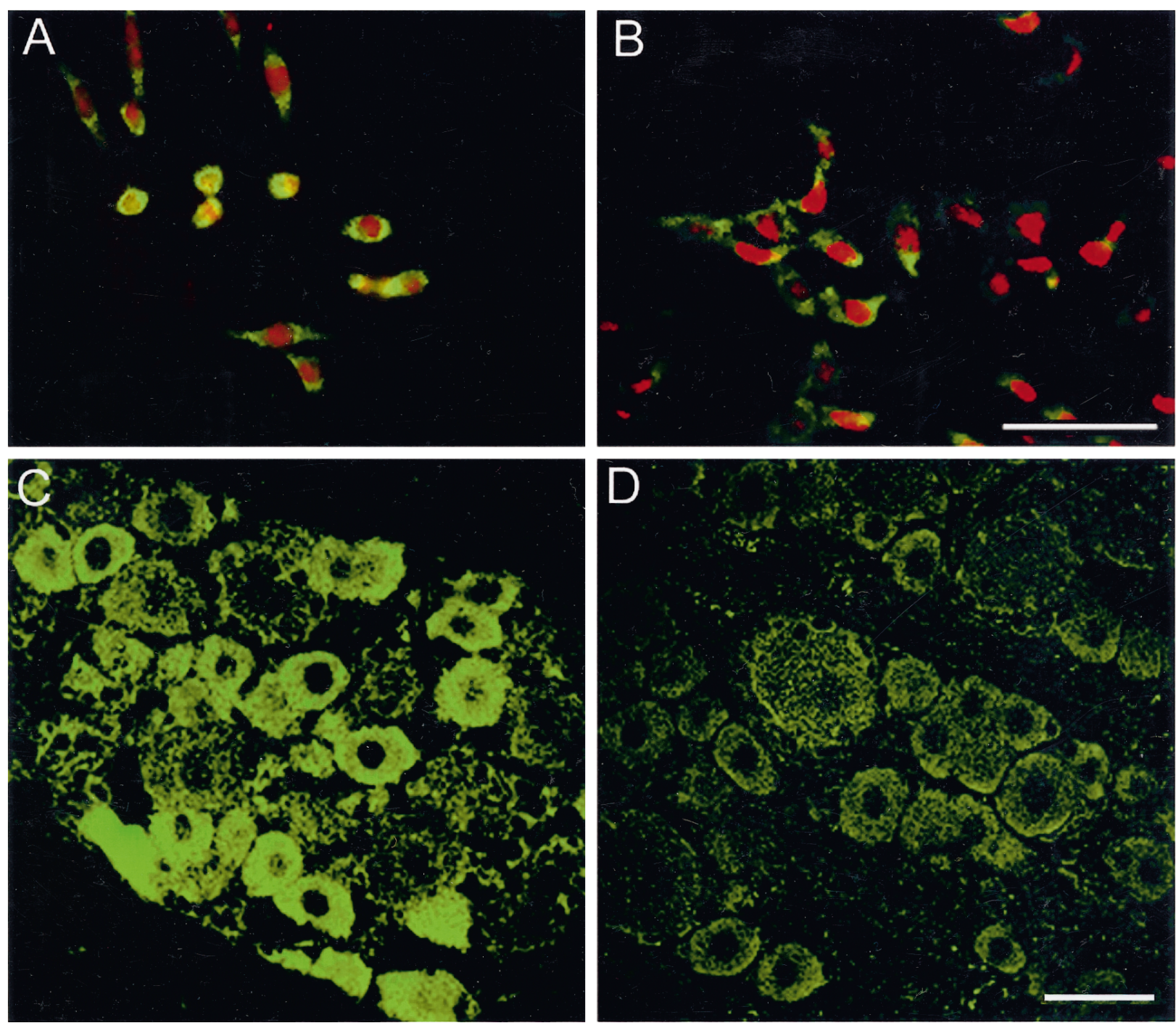

Figure 3. Immunocytochemistry of PN3 transfected cells and normal DRG tissue. $A, B$, Immunolabeling of PN3 transfected and nontransfected CHL cells was performed with specific antiserum as a measure of antibody specificity. Transfected cells are brightly labeled $(A$, green $)$ when compared with nontransfected cells $(B$, green). Propidium iodide was used for labeling of cell nuclei $(\mathrm{red})$. Scale bar, $25 \mu \mathrm{m}$. $C, D$, Immunofluorescence labeling of normal DRG tissue. In agreement with in situ hybridization (Fig. 2), small neurons exhibit a bright fluorescent signal ( $C$, green), compared with low-level labeling in large neurons and control with preabsorbed antibodies $(D)$. Scale bar, $50 \mu \mathrm{m}$.

(not shown), and was considered nonspecific. Cell nuclei were labeled with propidium iodide and are clearly visible (red fluorescence) in Figure $3 B$ because of the lack of PN3 labeling (green fluorescence).

In agreement with in situ hybridization, immunofluorescence of normal DRG sections showed high intensity labeling in small neurons (Fig. $3 C$ ), confirming the presence of PN3 protein in these cells. Some large DRG neurons were also labeled but with much lower intensity. When preabsorbed antibodies were used for immunolabeling, the specific signal disappeared (Fig. 3D). Similar observations were made when immunocytochemistry was performed on paraffin sections with peroxidase-DAB reaction, or on $20-\mu \mathrm{m}$-thick cryosections (not shown). PN3 immunolabeling was also observed in satellite cells, and it could be blocked with preabsorbed antibodies.

No immunolabeling was detected with PN3 antiserum in rat brain (Fig. $4 A$ ), thus confirming the RT-PCR data showing the exclusive localization of PN3 to the peripheral nervous system
(Sangameswaran et al., 1996). It also demonstrated that PN3 antibody (20075) did not cross-react with other sodium channel isoforms such as brain types I-III (Westenbroek et al., 1989), PN1/SCN9A (Sangameswaran et al., 1997), or PN4/SCN8A/ NaCh6 (Schaller et al., 1995), which are found abundantly in the brain. In addition, no immunolabeling was detected in heart sections showing that (1) the cardiac channel/SCN5A, which is amply expressed in the heart, is not labeled in these conditions, and (2) PN3 channel is not found in the heart. Furthermore, PN3 antibody did not label the node of Ranvier in normal myelinated fiber (as shown in Fig. 10C,G). The above findings all indicated the specificity of antisera for PN3.

The quantification of immunolabeling intensity confirmed our observations showing that the mean labeling intensity was highest in small neurons $\left(<700 \mu \mathrm{m}^{2}\right)$, somewhat lower in medium neurons (700-1200 $\left.\mathrm{mm}^{2}\right)$, and very low in large neurons $(>1200$ $\mu \mathrm{m}^{2}$ ) (Fig. 5A). A labeling intensity of 180 pixels/inch was found in cells labeled with preabsorbed antibodies, which was consid- 

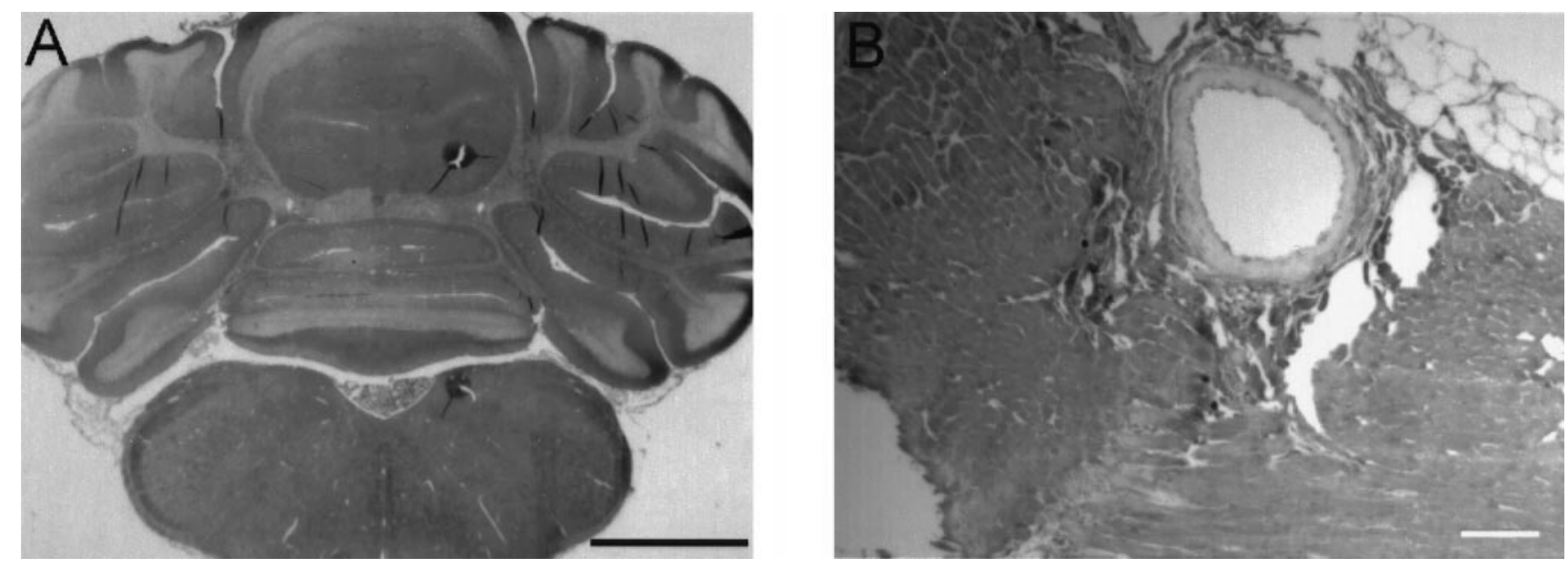

Figure 4. PN3 immunolabeling of brain and heart tissue. No specific PN3 labeling was detected in rat brain $(A)$ or heart tissue $(B)$ in the experimental conditions that we used (background labeling was identical with the preabsorbed control, not shown), thus confirming the exclusive localization of PN3 to the peripheral nervous system. It also demonstrated that PN3 antibody (20075) did not cross-react with any other sodium channel isoforms. Scale bar: $A, 200 \mu \mathrm{m} ; B, 50 \mu \mathrm{m}$.

ered to be background. Thus, only neurons with an intensity higher than 180 pixels/inch were considered positive. A histogram was generated (Fig. $5 B$ ) showing the percentage of PN3-positive cells and distribution by cell size. It was found that $93 \%$ of small cells $\left(<700 \mu \mathrm{m}^{2}\right)$ and $31 \%$ of medium cells $\left(700-1200 \mu \mathrm{m}^{2}\right)$ were positive for PN3. It was calculated that $78 \%$ of all small and medium cells were positive for PN3, which agrees with the percentage of small and medium neurons positive for PN3 mRNA (77\%) (Table 2). On the other hand, large cells $\left(>1200 \mu \mathrm{m}^{2}\right)$ were negative for PN3 immunolabeling, which differs from the finding that $44 \%$ of large neurons expressed PN3 mRNA (Table 2), as detected by in situ hybridization. This finding may imply some post-transcriptional regulation that controls PN3 protein level, or alternatively, PN3 may be synthesized in large neurons and transported to the peripheral axonal endings without a significant protein pool residing in the cell somata.

Fluorescently labeled cryosections were then used for confocal microscopy to determine the subcellular localization of PN3. Figure $6 A-F$ illustrates six optical sections, spaced by $1.8 \mu \mathrm{m}$, taken through a $20 \mu \mathrm{m}$ DRG section. The uniform pattern of labeling throughout the entire neuron indicates that much of the labeling is attributable to an intracellular pool of PN3 protein. Most of the PN3 protein appears to be located in the perinuclear region.

In the spinal cord, PN3 antiserum labeled predominantly the superficial laminae of the dorsal horn, as shown by peroxidaseDAB immunocytochemistry (Fig. 7A). This localization, as well as the lack of PN3 mRNA in the spinal cord, implied that labeling is caused by the protein content in the central terminals of the primary sensory neurons. The specific signal disappeared if preabsorbed antibodies were used (Fig. 7B).

\section{PN3 protein is translocated from DRG cell somata to their peripheral axons after neuropathic injury}

Immunolabeling of the DRG sections from sham-operated animals $7 \mathrm{~d}$ PS (Fig. 8A) revealed the same labeling pattern as in normal tissue (Fig. $4 C$ ). In the CCI tissue at $7 \mathrm{~d}$ PS, a slight decrease in labeling intensity of small cells could be observed (Fig. $8 B$ ). This change was more prominent at $14 \mathrm{~d} \mathrm{PS}$, leading to an entirely different immunolabeling pattern (Fig. $8 C$ ). Small and
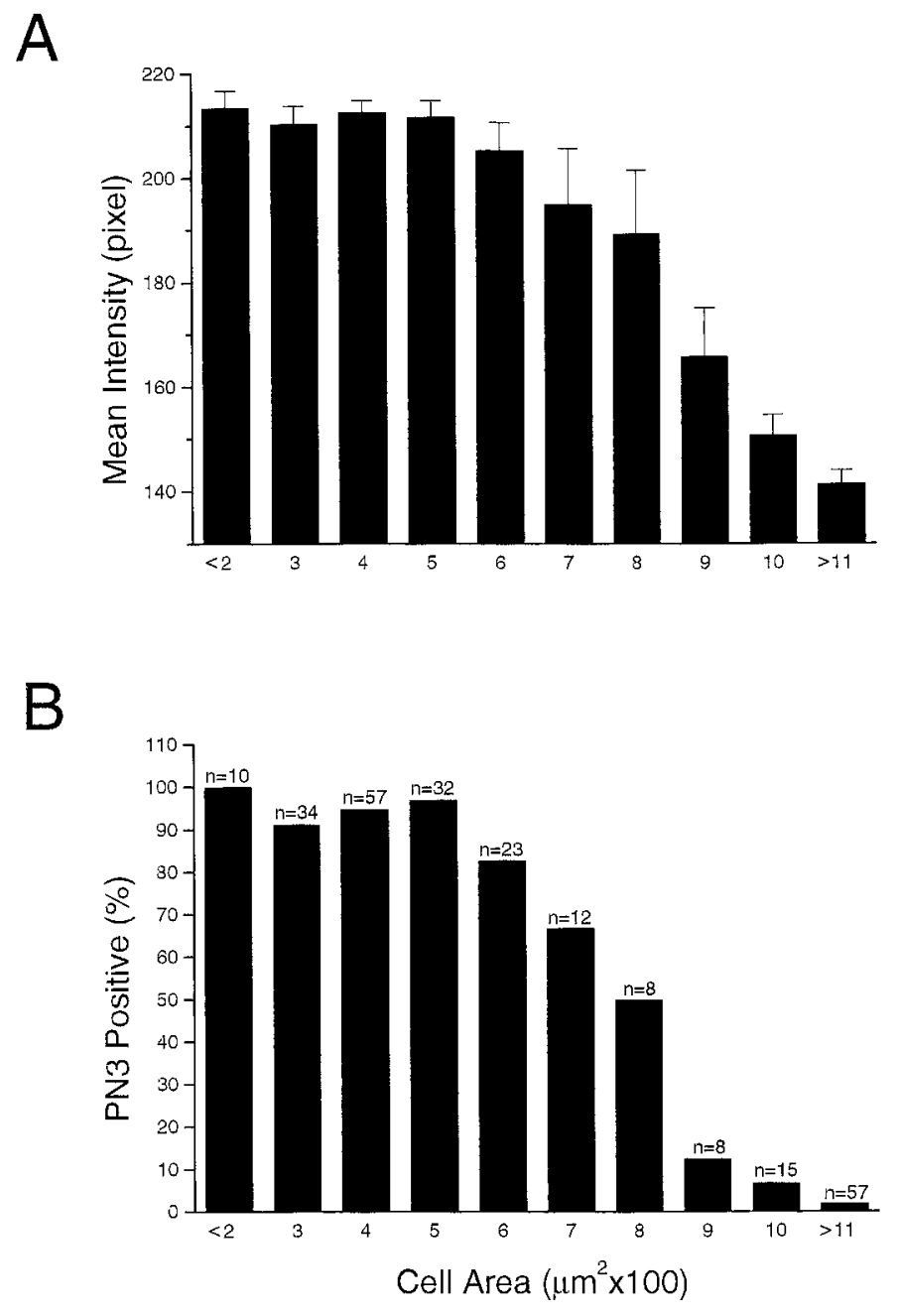

Figure 5. Quantification of immunolabeling in normal DRG. $A$, Mean intensity of immunolabeling according to cell size. $B$, Percentage of PN3-positive neurons according to cell size. 

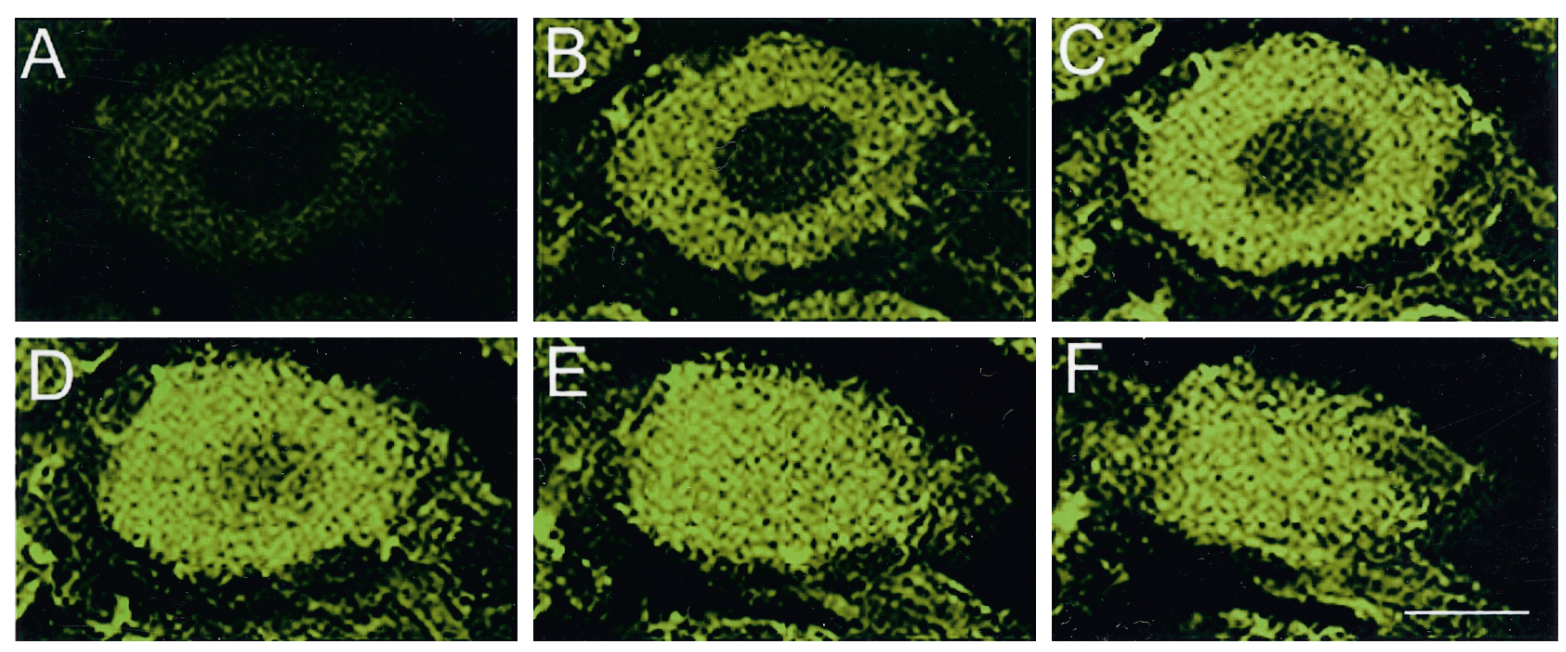

Figure 6. Confocal microscopy of PN3-labeled DRG cells. $A-F$, Six optical sections (at $1.8 \mu \mathrm{m}$ intervals) from a $20-\mu \mathrm{m}$-thick cryosection labeled with PN3 antiserum. This illustrates that most immunolabeling is located intracellularly. Scale bar, $10 \mu \mathrm{m}$.
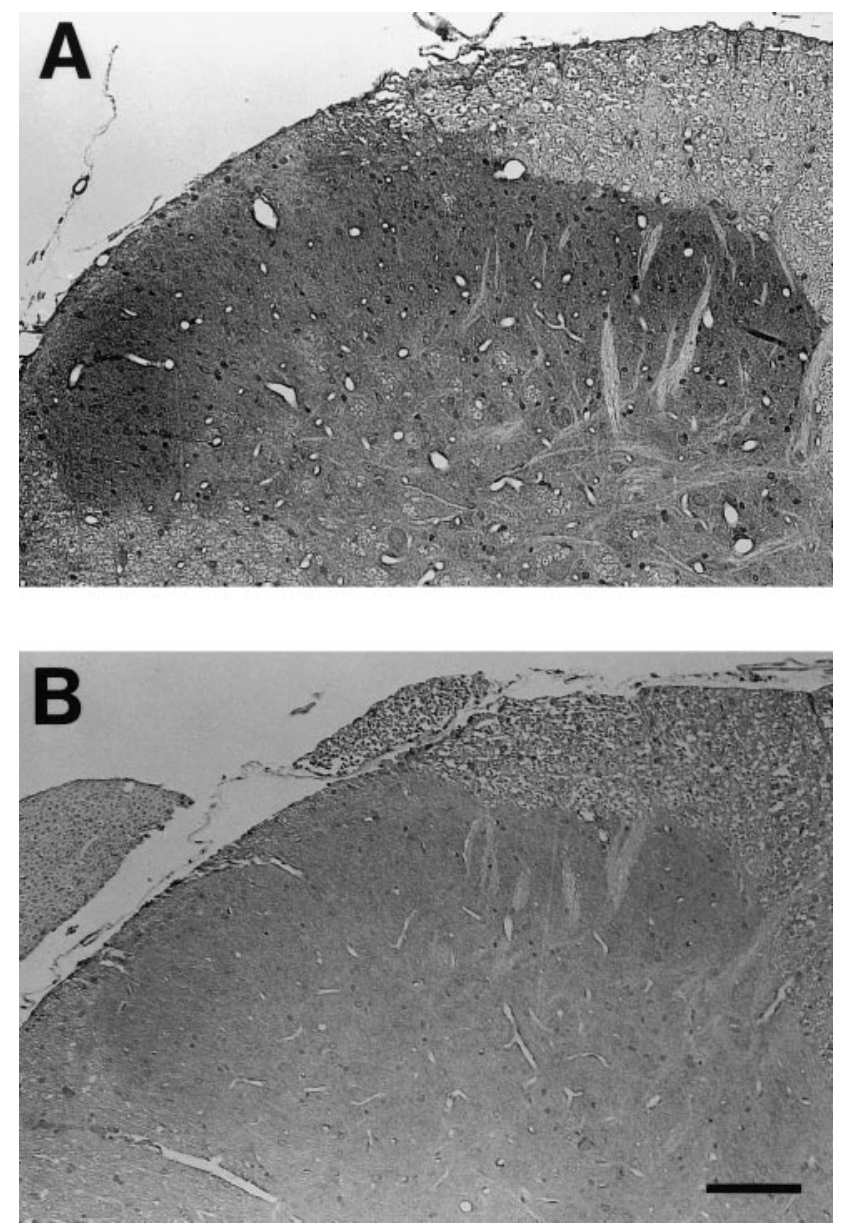

Figure 7. Immunolabeling of spinal cord section as revealed by immunoperoxidase-DAB. $A$, Specific PN3 labeling can be observed in the superficial laminae of the spinal cord dorsal horn. $B$, No labeling can be observed in preabsorbed antibody control. Scale bar, $100 \mu \mathrm{m}$.

large cells appeared to be uniformly labeled, in sharp contrast to immunolabeling of tissue from normal or sham-operated animals (Fig. 8A). Note that PN3 labeling of satellite cells remains unchanged in CCI tissue (Fig. $8 C$ ). At 28 d PS, the immunolabeling pattern returned to normal as small cells regained their high intensity labeling (Fig. 8D).

Digital measurements of labeling intensity confirmed our observations by showing that mean labeling intensity significantly decreased $(p<0.01)$ in small DRG neurons taken from CCI tissue when compared with neurons from sham-operated animals (Fig. 9A). Consequently the percentage of small neurons positive for PN3 decreased from 93 to $24 \%$ (Fig. 9B). The mean labeling intensity of medium and large cells and the percentage of positive medium and large cells did not change significantly in the CCI model.

The immunofluorescence of DRG sections and teased sciatic axons taken from sham-operated and CCI animals is illustrated in Figure 10. Data shown are obtained with two antisera: 20075 (left) and 20073 (right). If compared with tissue from shamoperated animals (Fig. 10A,E), DRG sections from CCI animals, $14 \mathrm{~d}$ PS, showed significant changes in pattern and intensity of labeling (Fig. 10B,F), as described previously (Fig. 8). In normal axons, PN3 immunofluorescence was not found (Fig. 10C, $G$ ), indicating that PN3, if present in normal fibers, has a low density that cannot be detected by immunocytochemistry at the light microscopy level. It must be noted, however, that we have not analyzed peripheral nerve endings where PN3 channels might be localized in higher density. In contrast to normal axons, PN3 labeling significantly increased along the CCI fibers, as observed by immunofluorescence $14 \mathrm{~d}$ PS (Fig. $10 D, H)$. Immunolabeling was observed primarily in very thin, presumably unmyelinated axons and new axonal sprouts. Demyelinated and unmyelinated axons could not be unequivocally distinguished, but most PN3-positive axons had very small diameters $(<1 \mu \mathrm{m})$ and therefore were considered unmyelinated or newly regenerating axons.

In the neuroma model, there was a change in the staining pattern similar to that seen in CCI tissue (Fig. 11). The normal labeling pattern, as seen in the section from a sham-operated animal, $5 \mathrm{~d}$ PS (Fig. 11 $A$ ), is lost in DRG section from an animal with a neuroma, $5 \mathrm{~d}$ PS (Fig. $11 B$ ). At $11 \mathrm{~d}$ PS, the immunolabeling appeared to be of the same intensity in all DRG cells (not shown), and this pattern still prevailed at $21 \mathrm{~d}$ PS (Fig. 11C). 

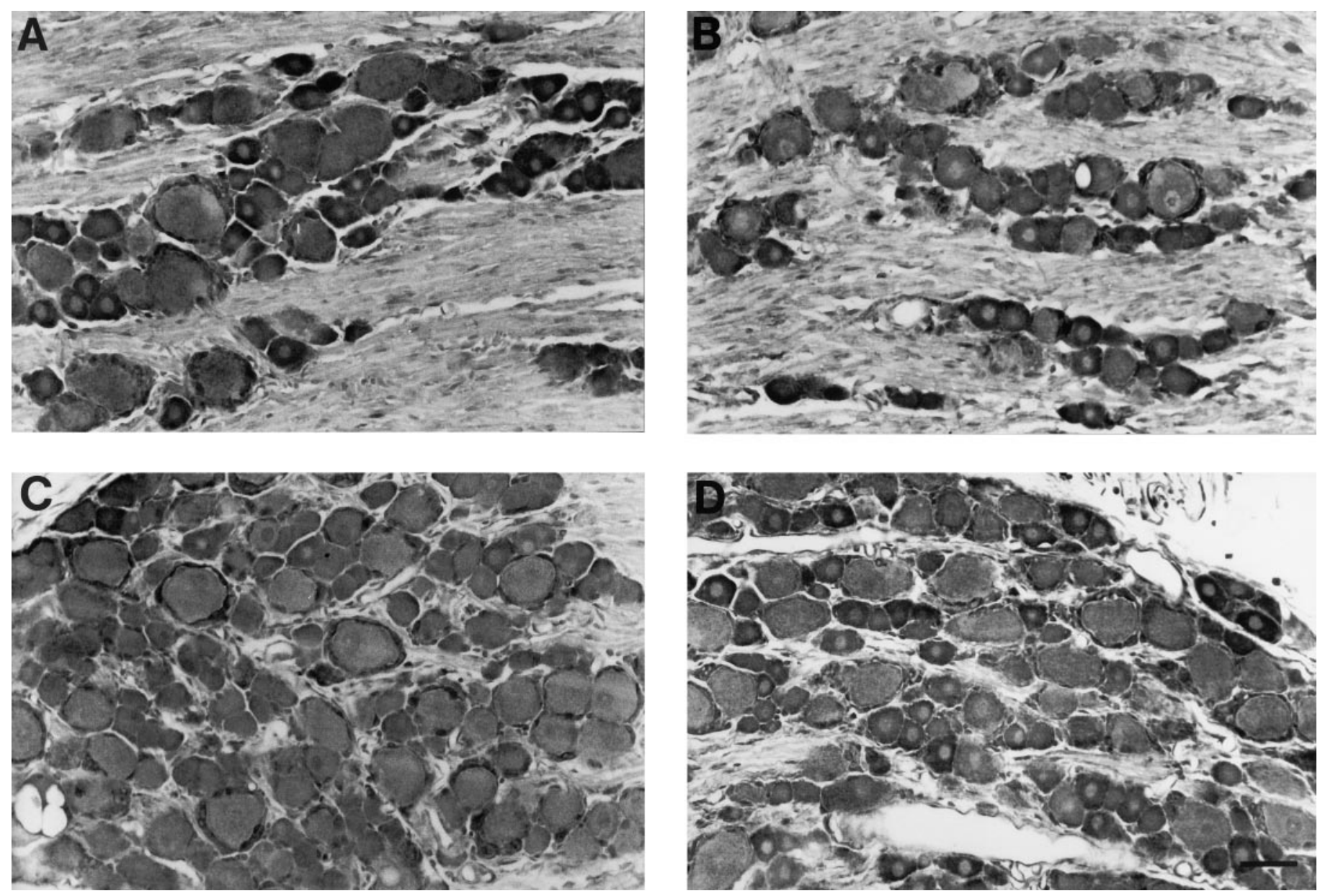

Figure 8. Immunocytochemistry (peroxidase-DAB) of DRG cells from sham-operated and CCI animals. $A$, Tissue from sham-operated animals revealed a similar labeling pattern as tissue from normal animals (shown in Fig. 3 by immunofluorescence), $7 \mathrm{~d}$ PS. $B$, CCI tissue, $7 \mathrm{~d}$ PS. Small cells have lost some of the high-intensity labeling. $C$, CCI tissue, $14 \mathrm{~d}$ PS. In contrast to tissue from sham-operated animals, immunolabeling is of the same intensity in small and large DRG cells. $D$, CCI, $28 \mathrm{~d}$ PS. The normal immunolabeling pattern reappears, with small cells regaining their high intensity labeling. Scale bar, $50 \mu \mathrm{m}$.

\section{DISCUSSION}

\section{PN3 sodium channel expression in small DRG neurons}

The size of DRG neurons correlates with axonal diameter and to some extent with the conduction velocities of the axons (Harper and Lawson, 1985). Small neurons give rise to slowly conducting, small-diameter myelinated $(\mathrm{A} \delta$ ) and unmyelinated $(\mathrm{C})$ fibers with a primary role in nociception. Our immunocytochemical findings showed that PN3 is expressed in $93 \%$ of small $\left(<700 \mu \mathrm{m}^{2}\right)$ and $31 \%$ of medium DRG neurons $\left(700-1200 \mu \mathrm{m}^{2}\right)$ but not in large neurons $\left(>1200 \mu \mathrm{m}^{2}\right)$. This compares with the in situ hybridization findings in which PN3 mRNA was detected in $77 \%$ of small and medium neurons and in $44 \%$ of large neurons. The localization of PN3 is therefore consistent with the hypothesis that this channel constitutes a major component of the $\mathrm{TTX}_{\mathrm{R}}$ sodium current measured in small neurons by the whole-cell patch-clamp method. These results are also consistent with previous findings that all small neurons (diameter $<30 \mu \mathrm{m}$ ), a population of medium neurons (diameter 30-50 $\mu \mathrm{m}$ ), and none of the large neurons (diameter $>50 \mu \mathrm{m}$ ) exhibited TTX $_{\mathrm{R}}$ current (Caffrey et al., 1992). A diameter of $<30 \mu \mathrm{m}$ corresponds roughly to a cell area $<700 \mu \mathrm{m}^{2}$, and a diameter of $<50 \mu \mathrm{m}$ to a cell area $<1900 \mu \mathrm{m}^{2}$. It must be noted, however, that this correlation is quite limited, because neuronal area cannot be accurately calculated from the cell diameter and also because cultured DRG neurons, as are used in electrophysiological studies, tend to flatten out and may have larger diameters than neurons in situ.

\section{Evidence for PN3 redistribution after neuropathic injury}

The electrophysiological measurements showed that $\mathrm{TTX}_{\mathrm{R}}$ sodium currents recorded from small DRG neurons did not change on day 12 after the CCI surgery. Furthermore, RT-PCR and in situ hybridization demonstrated that PN3 mRNA expression remained the same in the DRG tissue from CCI animals, up to $14 \mathrm{~d}$ PS. It has been reported previously, however, that both TTX $_{R}$ current and $\alpha$-SNS sodium channel mRNA are downregulated in DRG neurons after peripheral nerve axotomy (Dib-Hajj et al., 1996; Cummins and Waxman, 1997). Although there might be several explanations for this discrepancy, we feel the most parsimonious to be that it reflects a fundamental difference in the pathophysiology of the two models. This difference is clearly demonstrated by the appearance of stimulus-evoked, behavioral sensory abnormalities such as hyperalgesia and allodynia in the CCI model and their absence after nerve transection (Zeltser and Seltzer, 1994). In the sciatic neuroma model, complete nerve transection results in total deafferentation affecting the entire $\mathrm{C}$-fiber population of the sciatic, whereas in the CCI model, the 
A

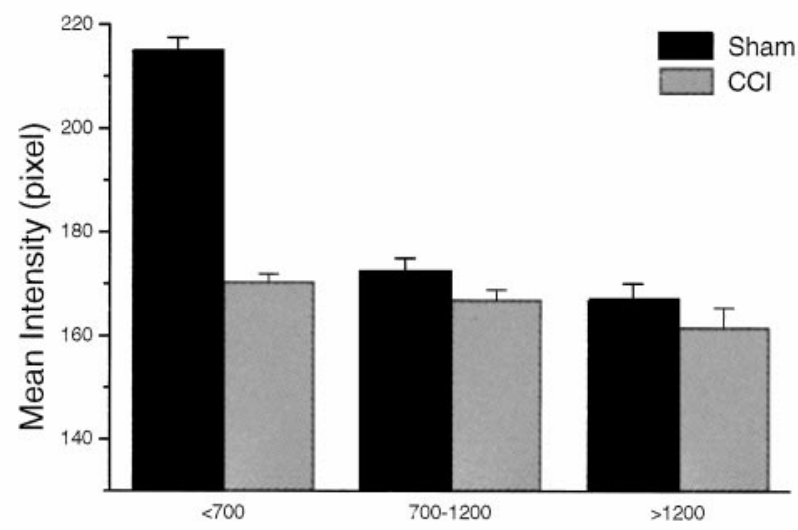

B

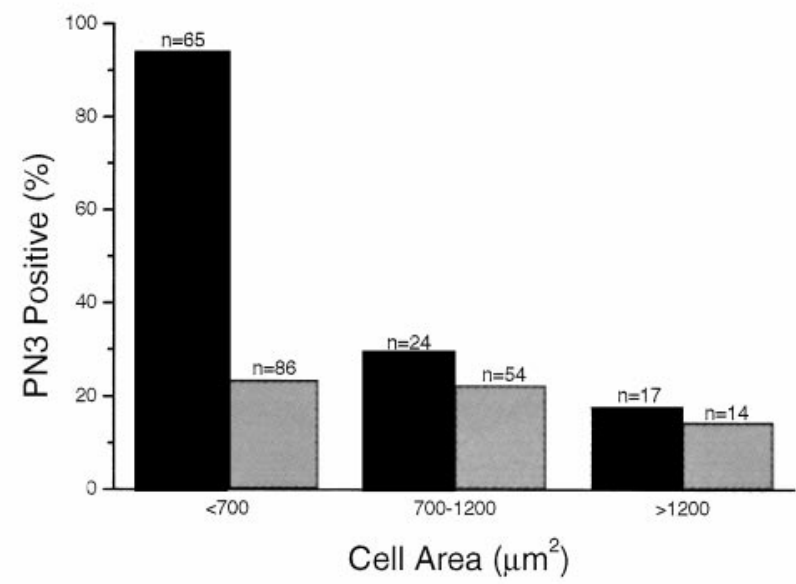

Figure 9. Mean labeling intensity and percentage of PN3-positive neurons in DRG taken from CCI and sham-operated animals, $14 \mathrm{~d}$ PS. $A$, Mean intensity of labeling in small $\left(<700 \mu \mathrm{m}^{2}\right)$, medium $(700-1200$ $\left.\mu \mathrm{m}^{2}\right)$, and large neurons $\left(>1200 \mu \mathrm{m}^{2}\right)$ taken from sham-operated (black bars) and CCI animals (gray bars). There is a significant difference in the intensity of labeling of small neurons from the two groups of animals. There is no significant difference in the intensity of labeling of medium and large neurons. $B$, Percentage of PN3-positive neurons in shamoperated (black bars) and CCI animals (gray bars). The percentage of small neurons positive for PN3 is significantly lower in tissue from CCI animals. The percentage of PN3-positive medium and large neurons does not differ significantly.

chromic gut ligatures produce only a partial deafferentation, and consequently a substantial but lesser proportion of C-fibers are affected by this type of injury (Coggeshall et al., 1993). Therefore, the lack of effect on sodium current density observed in the CCI model might be attributable to the sampling of enough uninjured neurons to obscure a reduction in $\mathrm{TTX}_{\mathrm{R}}$ current. However, if this were the case, then we might have expected to record two populations of small cells: one with normal and the other with reduced proportions of $\mathrm{TTX}_{\mathrm{R}}$ current. We did not observe two such populations of small neurons in tissue taken from CCI rats.

In contrast to the electrophysiological and in situ hybridization findings, immunocytochemical analysis showed significant differences in the labeling pattern and intensity in both CCI and neuroma tissues, when compared with tissues from shamoperated animals. The intensity of PN3 labeling in small DRG neurons decreased progressively on days 7 and 14 after the CCI surgery, with the normal pattern of high intensity labeling returning by day 28 PS. In the neuroma model, a similar progressive reduction in immunolabeling in the small neurons was observed from day 5 to $21 \mathrm{PS}$.

Although these electrophysiological and immunocytochemical findings at first seem contradictory, they can be explained by the nature of the two different methods. Thus, although electrophysiological measurements provide information on plasma membrane channels only, the immunolabeling represents both membrane and cytoplasmic sodium channels, as shown by the confocal analysis. The association of sodium channels with intracellular membranes in neurons has been noted previously and may reflect pools of unassembled $\alpha$-subunits (Schmidt et al., 1985). Thus, it is conceivable that the density of channels incorporated in the neuronal membrane remained the same, despite changes in immunolabeling intensity. Furthermore, the comparison of electrophysiological and immunocytochemical findings suggests that a specific translocation of intracellular PN3 protein took place after neuropathic injury.

Concomitant with changes in the immunolabeling pattern observed in the DRG cell somata, an increase in PN3 immunolabeling occurred in the peripheral fibers, implying a specific redistribution of PN3 channels from the cell body to the periphery. Because the half-life of sodium channels is only 1-3 d (Schmidt and Catterall, 1986), the axonal membrane is in a constant state of remodeling. Thus, it is conceivable that the accumulation of sodium channels in damaged peripheral axons would not always require de novo synthesis but could be the result of a modification in the normal process of channel insertion and recycling (Devor, 1995; Tzoumaka et al., 1995). Here, we show that PN3 channel accumulation at the site of injury is a dynamic process that at least for the post-surgery period studied does not require an enhanced synthesis but only an increased incorporation of existing PN3 channels into the peripheral axolemma.

\section{Why does PN3 translocation occur in neuropathy?}

Sodium channel protein is constantly synthesized in cell soma and conveyed to the axon end (Brismar and Gilly, 1987), presumably by rapid axoplasmic transport (Lombet et al., 1985). In addition, numerous studies have shown that sodium channels may be targeted to distinct parts of neuronal cell membranes (Ellisman and Levinson, 1982; Wollner et al., 1988; Westenbroek et al., 1989; Vabnick et al., 1996). Highly specialized sodium channel translocation followed by clustering in particular membrane regions, such as nodes of Ranvier (Dugandzija-Novakovic et al., 1995 ) or sensory terminals in afferent fibers, is of major importance in normal impulse conduction (Hille, 1991). Conversely, the disorganization and pathological redistribution of sodium channels may be the cause of significant alterations in nerve conduction. There are a few possible explanations for the sodium channel redistribution after neuropathic injury.

First, anterograde axonal transport is completely blocked in the neuroma model and is significantly reduced in the CCI model. Because sodium channels, presumably including $\mathrm{TTX}_{\mathrm{R}}$ channels, are constantly being transported to peripheral terminals, any alteration in the axonal transport would ultimately result in channel accumulation at the site of injury.

Second, after nerve degeneration and subsequent regeneration, many new axonal sprouts could be observed at the injury site in both CCI and neuroma models. Govrin-Lippmann and Devor (1978) have shown that the neuroma itself is a major site of 

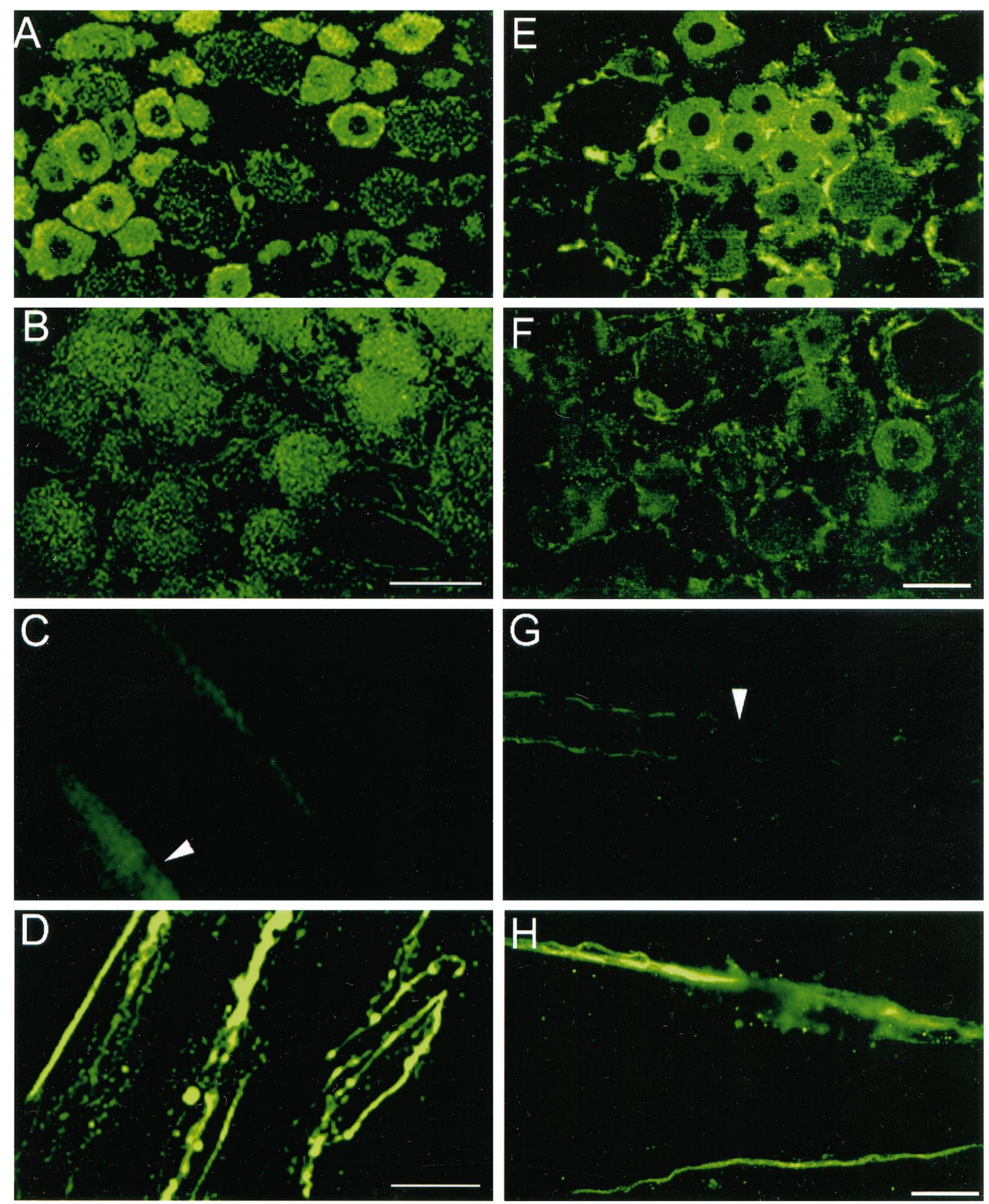

Figure 10. Immunofluorescence of CCI DRG cell somata and their peripheral axons. $A-D$ represent immunolabeling with antiserum 20075 , and $E-H$ show almost identical results reproduced with antiserum 20073. Fluorescent labeling of DRG tissue taken from sham-operated animals $(A, E), 14 \mathrm{~d}$ PS, which is the same as in normal tissue. In tissue from CCI animals, there is a dramatic reduction in labeling intensity in small cells $(B, F), 14 \mathrm{~d}$ PS. Scale bar, $50 \mu \mathrm{m}$. $C$ and $G$ represent fluorescent labeling of teased axons from normal sciatic nerve (arrows show unlabeled nodes of Ranvier). In axons from CCI animals, there is intense labeling $(D, H)$. Scale bar, $25 \mu \mathrm{m}$.

ectopic discharge in both myelinated and unmyelinated axons. Furthermore, they have located the hyperexcitability to the mechanosensitive "hot spots" found close to the cut nerve end. This zone is very rich in neuroma endbulbs and sprouts, the structures strongly implicated in ectopic signaling (Govrin-Lippmann and Devor, 1978) and sodium channel accumulation as shown in fish (Devor et al., 1989), rats (Devor et al., 1993), and humans (J. England et al., 1996). Our study shows that many of these new 

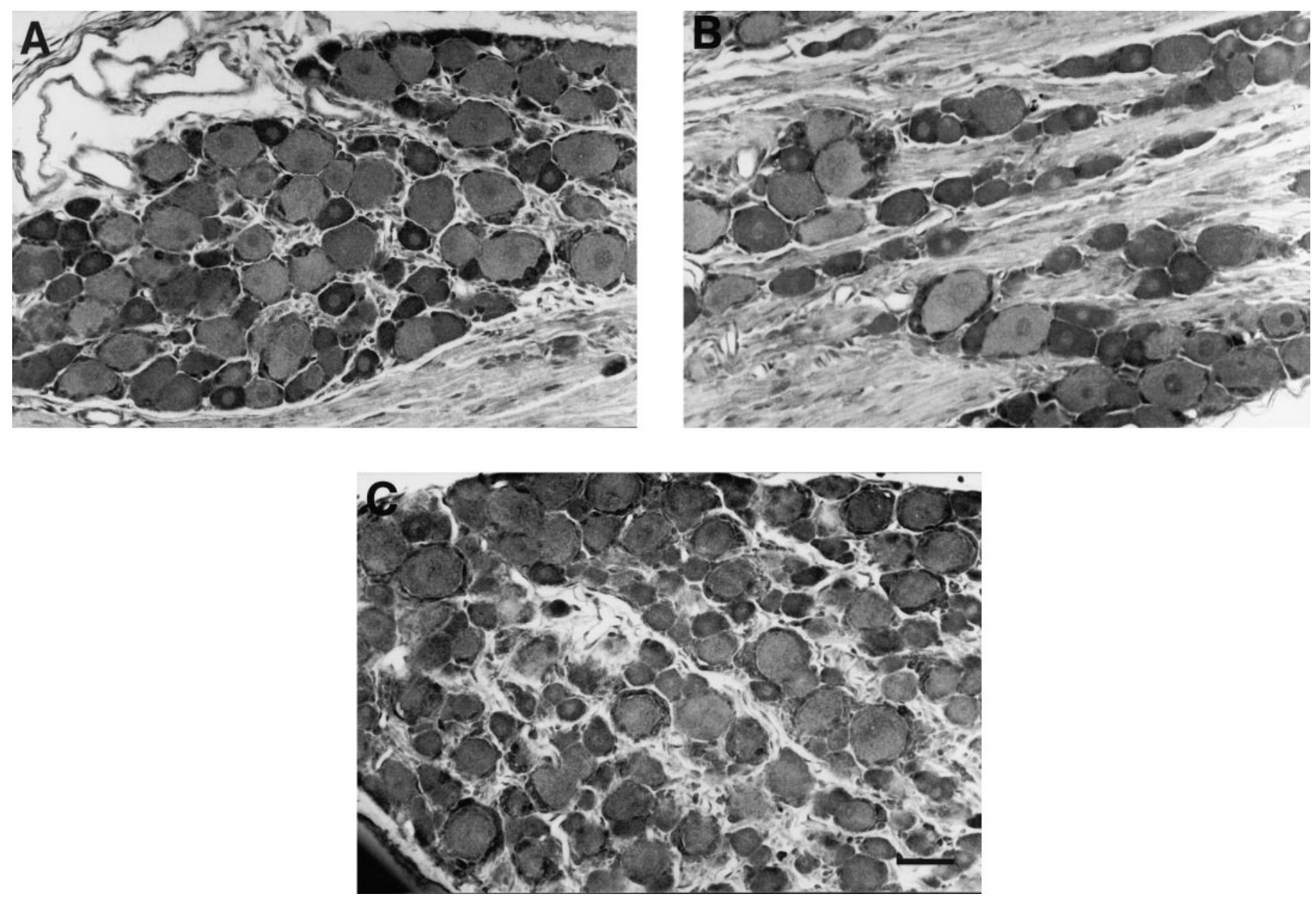

Figure 11. Immunohistochemistry (peroxidase-DAB) of DRG tissue from sham-operated and nerve-transected animals. $A$, Tissue section from sham-operated animal, $5 \mathrm{~d}$ PS. $B$, Section from animal with nerve transection, $5 \mathrm{~d}$ PS. $C$, Section from animal with nerve transection, $21 \mathrm{~d}$ PS. Scale bar, $50 \mu \mathrm{m}$.

sprouts appear to be immunopositive for PN3. It is possible that in regenerating fibers the overaccumulated sodium channels cannot be clustered properly, at least in the initial stage of the recovery, and they appear to spread and incorporate over long patches of axolemma.

Third, it has been shown that myelin has an inhibitory role in sodium channel insertion in axolemma and that demyelination represents a "permissive" factor for sodium channel accumulation in membrane regions that are normally nearly devoid of them (Bostock and Sears, 1978; Rasminsky, 1978; Ritchie, 1982; Black et al., 1991). Thus, axons that have been demyelinated may become hyperexcitable (Smith and McDonald, 1980). Although demyelination ultimately leads to conduction block, secondary membrane remodeling and resulting alteration in membrane electrical properties can induce hyperexcitability and associated positive sensory symptoms, including pain (Rasminsky, 1981).

\section{Correlation of the PN3 redistribution with pathohistological and behavioral changes}

In the CCI model most degenerative changes in the nerve peak around $14 \mathrm{~d}$ PS. There is a severe loss of fibers distal to the site of injury (Basbaum et al., 1991; Coggeshall et al., 1993). In the CCI model, spontaneous resorption of the chromic gut ligatures allows for a fast recovery process, so that by day 28 PS the number of myelinated and unmyelinated fibers has almost returned to normal (Coggeshall et al., 1993). These results clearly indicate that the intense degeneration/demyelination that takes place within the first 2 weeks after surgery is followed by an extensive regeneration/remyelination in the following weeks. This is consistent with observations that thermal hyperalgesia in CCI animals, as a measure of neuropathic pain, is maximal around day 14 PS (Bennett and Xie, 1988; Attal et al., 1990; Coggeshall et al., 1993). It is intriguing that the redistribution of PN3 immunolabeling in small DRG cells correlates with these pathohistological and behavioral changes. Later, as the regeneration proceeds and new axons are formed and become thinly myelinated (fourth week PS), PN3 immunolabeling in DRG neurons returns to normal. It has yet to be shown whether other changes, such as a modified expression of PN3 mRNA, occur in the later stages of neuropathy (>28 d PS).

Pathohistological changes associated with neuroma formation have been studied extensively (Fried and Devor, 1988; Fried et al., 1991). The main features of the neuroma model at 1-4 weeks PS include axonal degeneration/demyelination, terminal swelling or endbulb formation, and abortive axonal sprouting (Devor, 1995). Consequently, a membrane remodeling takes place in peripheral axons (Fried et al., 1991). In our study, the decrease in labeling intensity of small DRG cells was observed on days 5, 11, and 21 PS. Although later post-surgery days were not studied 
here, it might be expected that changes in the PN3 immunolabeling pattern in the neuroma model would persist for a longer period of time, corresponding to an abortive process of regeneration.

\section{The significance of the PN3 accumulation in peripheral nerve fibers}

$\mathrm{TTX}_{\mathrm{R}}$ sodium currents have been shown by electrophysiological methods to be present in nociceptive afferents and are strongly implicated in nociceptive processing (Koerber and Mendell, 1992; Jeftinija, 1994a; Gold et al., 1996). TTX ${ }_{\mathrm{R}}$ sodium channels, including PN3, are distinguished by slow kinetics and their requirement for a higher depolarization for activation (Kostyuk et al., 1981; McLean et al., 1988). Thus, C fibers containing TTX $_{R}$ channels have a higher threshold for action potential generation and normally are silent. In neuropathic conditions, however, $\mathrm{TTX}_{\mathrm{R}}$ channels may be involved in the coding of sensory information (Rang et al., 1995), resulting in the establishment and maintenance of central sensitization, a key feature of neuropathic pain state. It has been shown that in a neuroma the discharge of $\mathrm{C}$ fibers is quantitatively different from the discharge originating in A fibers (Devor, 1995), further implying the importance of specific sodium channel isoform(s) in ectopic electrogenesis.

In conclusion, the specific change in PN3 distribution found during neuropathic conditions suggests a dynamic involvement of this particular sodium channel isoform in the generation of nociceptive impulses. The fact that PN3 is pharmacologically distinct from all other known sodium channels and appears to be predominantly confined to the peripheral nervous system offers the prospect of new therapeutic approaches to neuropathic pain.

\section{REFERENCES}

Akopian AN, Sivilotti L, Wood JN (1996) A tetrodotoxin-resistant voltage-gated sodium channel expressed by sensory neurons. Nature 379:257-262.

Arbuckle JB, Docherty RJ (1995) Expression of tetrodotoxin-resistant sodium channels in capsaicin-sensitive dorsal root ganglion neurons of adult rats. Neurosci Lett 185:70-73.

Attal N, Jazat F, Kayser V, Guilbaud G (1990) Further evidence for pain-related behaviours in a model of unilateral peripheral mononeuropathy. Pain 41:235-251.

Basbaum AI, Gautron M, Jazat F, Mayes M, Guilbaud G (1991) The spectrum of fiber loss in a model of neuropathic pain in the rat: an electron microscopic study. Pain 47:359-367.

Bennett GJ, Xie YK (1988) A peripheral mononeuropathy in rat that produces disorders of pain sensation like those seen in man. Pain 33:87-107.

Black JA, Felts P, Smith KJ, Kocsis JD, Waxman SG (1991) Distribution of sodium channels in chronically demyelinated spinal cord axons: immuno-ultrastructural localization and electrophysiological observations. Brain Res 544:59-70.

Bley KR, Khabbaz M, Blissard DD, Lee C, Hunter JC (1995) Extracellular application of QX-314 blocks sodium channels and causes local anesthesia. Soc Neurosci Abstr 21:716.7.

Bostock H, Sears TA (1978) The internodal axon membrane: electrical excitability and continuous conduction in segmental demyelination. J Physiol (Lond) 280:273-301.

Brismar T, Gilly WF (1987) Synthesis of sodium channels in the cell bodies of squid giant axons. Proc Natl Acad Sci USA 84:1459-1463.

Burchiel KJ (1988) Carbamazepine inhibits spontaneous activity in experimental neuromas. Exp Neurol 102:249-253.

Caffrey JM, Eng DL, Black JA, Waxman SG, Kocsis JD (1992) Three types of sodium channels in adult rat dorsal root ganglion neurons. Brain Res 592:283-297.

Chabal C, Russell LC, Burchiel KJ (1989) The effect of intravenous lidocaine, tocainide and mexiletine on spontaneously active fibers originating in rat sciatic neuromas. Pain 38:333-338.

Coggeshall RE, Dougherty PM, Pover CM, Carlton SM (1993) Is large myelinated fiber loss associated with hyperalgesia in a model of experimental peripheral neuropathy in the rat? Pain 52:233-242.

Cummins TR, Waxman SG (1997) Downregulation of tetrodotoxinresistant sodium currents and upregulation of a rapidly repriming tetrodotoxin-sensitive current in small spinal sensory neurons after nerve injury. J Neurosci 17:3503-3514.

Devor M (1995) The pathophysiology of damaged peripheral nerves. In: Textbook Of pain (Wall PD, Melzack R, eds), pp 79-100. New York: Churchill Livingstone.

Devor M, Bernstein JJ (1982) Abnormal impulse generation in neuromas: electrophysiology and ultrastructure. In: Abnormal nerves and muscles and impulse generation (Ochoa J, Culp W, eds), pp 363-380. Oxford: Oxford UP.

Devor M, Keller CH, Deerinck TJ, Levinson SR, Ellisman MH (1989) $\mathrm{Na}^{+}$channel accumulation on axolemma of afferent endings in nerve end neuromas in Apteronotus. Neurosci Lett 102:149-154.

Devor M, Govrin-Lippmann R, Angelides K (1993) $\mathrm{Na}^{+}$channel immunolocalization in peripheral mammalian axons and changes following nerve injury and neuroma formation. J Neurosci 13:1976-1992.

Dib-Hajj S, Black JA, Felts P, Waxman SG (1996) Down-regulation of transcripts for Na channel $\alpha$-SNS in spinal sensory neurons following axotomy. Proc Natl Acad Sci USA 93:14950-14954.

Dugandzija-Novakovic S, Koszowski AG, Levinson SR, Shrager P (1995) Clustering of $\mathrm{Na}^{+}$channels and node of Ranvier formation in remyelinating axons. J Neurosci 15:492-503.

Elliott AA, Elliott JR (1993) Characterization of TTX-sensitive and TTX-resistant sodium currents in small cells from adult rat dorsal root ganglia. J Physiol (Lond) 463:39-56.

Ellisman MH, Levinson SR (1982) Immunocytochemical localization of sodium channel distributions in the excitable membranes of Electrophorus electricus. Proc Natl Acad Sci USA 79:6707-6711.

England JD, Happel LT, Kline DG, Gamboni F, Thouron CL, Liu ZP, Levinson S (1996) Sodium channel accumulation in humans with painful neuromas. Neurology 47:272-276.

England S, Bevan S, Docherty RJ (1996) $\mathrm{PGE}_{2}$ modulates the tetrodotoxin-resistant sodium current in neonatal rat dorsal root ganglion neurones via the cyclic AMP-protein kinase A cascade. J Physiol (Lond) 495:429-440.

Fried K, Devor M (1988) End-structure of afferent axons injured in the peripheral and central nervous system. Somatosens Mot Res 6:79-99.

Fried K, Govrin-Lippmann R, Rosenthal F, Ellisman MH, Devor M (1991) Ultrastructure of afferent axon endings in a neuroma. J Neurocytol 20:682-701.

Gold MS, Reichling DB, Shuster MJ, Levine JD (1996) Hyperalgesic agents increase a tetrodotoxin-resistant $\mathrm{Na}^{+}$current in nociceptors. Proc Natl Acad Sci USA 93:1108-1112.

Govrin-Lippmann R, Devor M (1978) Ongoing activity in severed nerves: source and variation with time. Brain Res 159:406-410.

Hamill OP, Marty A, Neher E, Sakmann B, Sigworth FJ (1981) Improved patch-clamp techniques for high-resolution current recording from cells and cell-free membrane patches. Pflügers Arch 391:85-100.

Harper, AA, Lawson, SN (1985) Electrical properties of rat dorsal root ganglion neurons with different peripheral nerve conduction velocities. J Physiol (Lond) 359:47-63.

Hille B (1991) Ionic channels of excitable membranes. Sunderland, MA: Sinauer.

Jeftinija S (1994a) The role of tetrodotoxin-resistant sodium channels of small primary afferent fibers. Brain Res 639:125-134.

Jeftinija S (1994b) Bradykinin excites tetrodotoxin-resistant primary afferent fibers. Brain Res 665:69-76.

Koerber HR, Mendell LM (1992) Functional heterogeneity of dorsal root ganglion cells. In: Sensory neurons: diversity, development and plasticity (Scott SA, ed). New York: Oxford UP.

Kostyuk PG, Veselovsky NS, Tsyndrenko AY (1981) Ionic currents in the somatic membrane of rat dorsal root ganglion cells. Neuroscience 6:2423-2430.

Lombet A, Laduron P, Mourre C, Jacomet Y, Lazdunski M (1985) Axonal transport of the voltage-dependent $\mathrm{Na}^{+}$channel protein. Brain Res 345:153-158.

Matzner O, Devor M (1992) $\mathrm{Na}^{+}$conductance and the threshold for repetitive neuronal firing. Brain Res 597:92-98.

Matzner O, Devor M (1994) Hyperexcitability at sites of nerve injury depends on voltage-sensitive $\mathrm{Na}^{+}$channels. J Neurophysiol 72:349-359.

McLean MJ, Bennett PB, Thomas RM (1988) Subtypes of dorsal root 
ganglion neurons based on different inward currents as measured by whole-cell voltage clamp. Mol Cell Biochem 80:95-107.

Ogata N, Tatebayashi H (1993) Kinetic analysis of two types of $\mathrm{Na}$ channels in rat dorsal root ganglia. J Physiol (Lond) 466:9-37.

Omana-Zapata I, Khabbaz M, Hunter JC, Clarke DE, Bley KR (1997)

Tetrodotoxin inhibits neuropathic ectopic activity in neuromas, dorsal root ganglia and dorsal horn neurons. Pain 72:41-49.

Rang HP, Bevan S, Dray A (1995) Nociceptive peripheral neurons: cellular properties. In: Textbook Of pain (Wall PD, Melzack R, eds), pp 57-78. New York: Churchill Livingstone.

Rasminsky M (1978) Ectopic generation of impulses and cross-talk in spinal nerve roots of dystrophic mice. Ann Neurol 3:351-357.

Rasminsky M (1981) Hyperexcitability of pathologically myelinated axons and positive symptoms in multiple sclerosis. In: Demyelinating diseases: basic and clinical electrophysiology (Waxman SG, Ritchie JM, eds), pp 289-297. New York: RP.

Ritchie JM (1982) Sodium and potassium channels in regenerating and developing mammalian myelinated nerves. Proc R Soc Lond B Biol Sci 215:273-287.

Sangameswaran L, Delgado SG, Fish LM, Koch BD, Jakeman LB, Stewart GR, Sze P, Hunter JC, Eglen RM, Herman RC (1996) Structure and function of a novel voltage-gated, tetrodotoxin-resistant sodium channel specific to sensory neurons. J Biol Chem 271:5953-5956.

Sangameswaran L, Fish LM, Koch BD, Rabert DK, Delgado SG, Ilnicka M, Jakeman LB, Novakovic S, Wong K, Sze P, Tzoumaka E, Stewart GR, Herman RC, Chan H, Eglen RM, Hunter JC (1997) A novel tetrodotoxin-sensitive sodium channel expressed in rat and human dorsal root ganglia. J Biol Chem 272:14805-14809.

Schaller KL, Krzemien DM, Yarowsky PJ, Krueger BK, Caldwell JH (1995) A novel, abundant sodium channel expressed in neurons and glia. J Neurosci 15:3231-3242.

Schmidt JW, Catterall WA (1986) Biosynthesis and processing of the alpha subunit of the voltage-sensitive sodium channel in rat brain neurons. Cell 46:437-444.

Schmidt JW, Rossie S, Catterall WA (1985) A large intracellular pool of inactive $\mathrm{Na}$ channel alpha subunits in developing rat brain. Proc Natl Acad Sci USA 82:4847-4851.

Smith KJ, McDonald WI (1980) Spontaneous and mechanically evoked activity due to central demyelinating lesion. Nature 286:154-155.
Study RE, Kral M (1996) Spontaneous action potential activity in isolated dorsal root ganglion neurons from rats with a painful neuropathy. Pain 65:235-242.

Tanelian DL, Victory RA (1995) Sodium channel blocking agents: their use in neuropathic pain conditions. Pain Forum 4:75-80.

Toledo-Aral JJ, Moss BL, He Z-J, Koszowski AG, Whisenand T, Levinson SR, Wolf JJ, Silos-Santiago I, Halegoua S, Mandel G (1997) Identification of PN1, a predominant voltage-dependent sodium channel expressed principally in peripheral neurons. Proc Natl Acad Sci USA 94:1527-1532.

Tzoumaka EE, Novakovic SD, Levinson SR, Shrager P (1995) $\mathrm{Na}^{+}$ channel aggregation in remyelinating mouse sciatic axons following transection. Glia 15:188-194.

Vabnick I, Novakovic SD, Levinson SR, Schachner M, Shrager P (1996) The clustering of axonal sodium channels during development of the peripheral nervous system. J Neurosci 16:4914-4922.

Waxman SG, Kocsis JD, Black JA (1994) Type III sodium channel mRNA is expressed in embryonic but not adult spinal sensory neurons and is re-expressed following axotomy. J Neurophysiol 72:466-470.

Westenbroek RE, Merrick DK, Catterall WA (1989) Differential subcellular localization of the RI and RII Na ${ }^{+}$channel subtypes in central neurons. Neuron 3:695-704.

Wollner DA, Scheinman R, Catterall WA (1988) Sodium channel expression and assembly during development of retinal ganglion cells. Neuron 1:727-737.

Xie Y, Zhang J, Petersen M, LaMotte RH (1995) Functional changes in dorsal root ganglion cells after chronic nerve constriction in the rat. J Neurophysiol 73:1811-1820.

Yaari Y, Devor M (1985) Phenytoin suppresses spontaneous ectopic discharge in rat sciatic nerve neuromas. Neurosci Lett 58:117-122.

Zeltser R, Seltzer Z (1994) A practical guide for the use of animal models in the study of neuropathic pain. Touch, temperature and pain in health and disease: mechanisms and assessments, progress in pain research and management, Vol III (Boivie J, Hansson P, Lindblom U, eds) pp 295-338. Seattle: IASP Press.

Zimmerman M (1983) Ethical guidelines for investigations of experimental pain in conscious animals. Pain 16:109-110. 